\author{
ARTUR HAMRYSZCZAK* - LUBLIN \\ HUBERT MĄCIK** - RZESZÓW
}

\title{
KOŚCIOLY I ZABUDOWANIA PARAFIALNE W KONOPNICY W XVII-XX WIEKU
}

\section{Streszczenie}

Parafia w Konopnicy w ziemi lubelskiej i archidiakonacie lubelskim datuje się na XIV wiek. Obejmowała trzy wsie położone koło siebie: Konopnicę, Radawiec i Uniszowice. Pod koniec XVIII wieku parafia liczyła już sześć wsi, obok wyżej wspomnianych miejscowości, także Radawczyk, Motycz i Sporniak. Zmiana granic parafii dokonała się dopiero w okresie międzywojennym, kiedy powstała parafia w Motyczu.

Uposażenie kościoła zostało nadane przez radę miasta Lublina w $1428 \mathrm{r}$. Najstarszy kościół drewniany pw. św. Katarzyny został zastąpiony po $1650 \mathrm{r}$. murowanym, konsekrowanym w 1667 r., zbudowanym na cyplu wysuniętym w dolinę rzeczki. Kościół nosił wówczas wezwanie, oprócz dotychczasowego św. Katarzyny, również Wniebowzięcia NMP.

Następcą tej świątyni jest wzniesiony w latach 1904-1906 kościół eklektyczny, według projektu Władysława Siennickiego, który funkcjonuje do dziś dnia i został wybudowany w innym miejscu niż poprzednia świątynia. Decyzja o jego wzniesieniu wynikała z rosnącej liczby mieszkańców parafii, złym stanem technicznym dotychczasowego kościoła oraz wytyczeniem szosy kraśnickiej, która stała się głównym traktem prowadzącym z Lublina do Kraśnika. Po wzniesieniu nowego kościoła, budynek starej świątyni z XVII wieku popadł w zapomnienie i w latach międzywojennych uległ rozbiórce.

W kościele w Konopnicy znajdowała się gotycka figura Piety, która aktualnie jest przechowywana w Muzeum Narodowym w Poznaniu. Rzeźba uchodziła za słynącą łaskami i cieszyła się lokalnym kultem. Umieszczona

\footnotetext{
* Artur Hamryszczak - dr historii; asystent naukowy w Ośrodku Archiwów, Bibliotek i Muzeów Kościelnych KUL; e-mail: artur.hamryszczak@kul.pl https://orcid.org/0000-0002-2578-9971

** Hubert Mącik - dr historii sztuki; adiunkt w Instytucie Archeologii Uniwersytetu Rzeszowskiego; e-mail: hubertmacik@gmail.com

https://orcid.org/0000-0002-8508-6768
} 
była w głównym ołtarzu. Corocznie w święto Siedmiu Boleści Maryi, w piątek przed Niedzielą Palmową odprawiano mszę św. odpustową z wystawieniem Najświętszego Sakramentu.

Szczegółowe opisy parafii i kościoła parafialnego w Konopnicy pochodzą z wizytacji kanonicznych, w których na przestrzeni lat zapisywano stan zabudowań kościelnych. Do zabudowań parafialnych oprócz kościoła należała plebania, mieszkania sług kościelnych, szpital oraz budynki gospodarcze (m.in. wozownia, stajnia, chlew, spichlerz, browar). Nowy cmentarz parafialny, który zastąpił przykościelny, powstał w początkach XIX wieku i aktualnie wpisany jest do rejestru zabytków.

Słowa kluczowe: Konopnica; Pieta; parafia w Konopnicy; archidiakonat lubelski; Władysław Sienicki; architektura sakralna

\section{Zarys historii parafii}

Konopnica, wieś położona historycznie w ziemi lubelskiej i archidiakonacie lubelskim doczekała się już pewnego zakresu opracowań historycznych. Dotychczas skupiano się jednak głównie na dziejach Konopnicy do końca wieku XVI, w mniejszym zaś stopniu na późniejszej historii ${ }^{1}$. Nie doczekały się jak dotąd bliższego opracowania konopnickie kościoły. Przedmiotem niniejszego artykułu jest omówienie na tle dziejów parafii historii konopnickich świątyń, a w szczególności próba rekonstrukcji drugiego z konopnickich kościołów, a pierwszego murowanego $\mathrm{w}$ tej parafii, pochodzącego z lat 60. XVII wieku oraz omówienie architektury nowszego kościoła zachowanego do dziś. Oba te obiekty właściwie nie są obecne w literaturze naukowej. Co prawda można by twierdzić, że ich jakość artystyczna (zwłaszcza w przypadku kościoła starego) niekoniecznie prede-

${ }^{1}$ Oprócz ogólnych opracowań, w których historia Konopnicy pojawia się na tle regionu np. Dzieje Lubelszczyzny, t. 3: Stownik historyczno-geograficzny województwa lubelskiego w średniowieczu, opr. S. Kuraś, Warszawa 1983; A. Sochacka, Wtasność ziemska w województwie lubelskim w średniowieczu, Lublin 1987; J. Chachaj, Bliżej schizmatyków niż Krakowa. Archidiakonat lubelski w XV i XVI wieku, Lublin 2012), należy tu wspomnieć szczegółowe publikacje: Księga sądowa podlubelskiej wsi Konopnicy 1521-1555, opr. G. Jawor, M. Kołacz-Chmiel, Lublin 2009; M. Kołacz-Chmiel, Elity chłopskie w Polsce w XV-XVI wieku. (Rodziny Bąków-Tomczyków i Zegadłów w podlubelskiej wsi Konopnica), „Średniowiecze Polskie i Powszechne”, 7 (2011) s. 186-204; A. Rola, Historia podlubelskiej wsi Konopnica do polowy XVI wieku, „Rocznik Lubelski”, 39 (2013) s. 9-19; P. Rachwał, Spis ludności parafii Konopnica z 1760 roku, „Przeszłość Demograficzna Polski”, 38 (2016) nr 2, s. 117-133. Dokładniejsze omówienie historii własnościowej wsi w XVII-XIX wieku znalazło się w niepublikowanym niestety opracowaniu K. Słowika, Konopnica, woj. lubelskie. Studium historyczno-ruralistyczne, Lublin 1991, mps, Archiwum Wojewódzkiego Urzędu Ochrony zabytków w Lublinie, sygn. 2130. Syntetyczne informacje o konopnickich kościołach zawarto w popularnym artykule: H. Mącik, Konopnickie kościoły, w: Węglin, Szerokie, red. H. Mącik, D. Szulc, J. Chachaj, Lublin 2017, s. 16-18. W tej samej publikacji znalazł się także komunikat o stanie badań archeologicznych części obszaru dawnej Konopnicy: R. Niedźwiadek, Węglin jako potencjalne miejsce osadnictwa pradziejowego $i$ wczesnośredniowiecznego?, w: Węglin, Szerokie, red. H. Mącik, D. Szulc, J. Chachaj, Lublin 2017, s. 8-9. Pewne uwagi o historii Konopnicy i konopnickiej parafii poczynili też autorzy monografii sąsiedniego Motycza: D. Kupisz, A. Obara, K.P. Pękała, Dzieje Motycza na przestrzeni wieków, Lublin 2010. 
stynuje je do zajmowania ważniejszych pozycji w syntezach architektury w skali Polski czy regionu lubelskiego, jednak należy stanowczo zauważyć, że pełne ujęcie krajobrazu architektonicznego danego regionu czy całego kraju powinno być złożone zarówno z obiektów wybitnych, jak i przeciętnych, które w swojej masie ten krajobraz budują najsilniej. Dotyczy to szczególnie budowli nieistniejących obecnie lub zachowanych reliktowo, które nierzadko pomijane są w literaturze przedmiotu ${ }^{2}$, podczas gdy mogą stanowić istotny - $\mathrm{z}$ różnych powodów - element całościowego ujęcia problemu.

Szczególnie cenne dla omówienia niezachowanego kościoła i towarzyszących mu zabudowań są staropolskie wizytacje biskupie archidiakonatu lubelskiego diecezji krakowskiej, zachowane z Archiwum Archidiecezjalnym Lubelskim (zwłaszcza obszerne opisy z lat 1675, 1748 i 1781) ${ }^{3}$ oraz w Archiwum Kurii Metropolitalnej Krakowskiej (w szczególności szczegółowy protokół wizytacji z roku 1721$)^{4}$. Ponadto istotne informacje, które zostały wykorzystane w niniejszym

${ }^{2}$ Bywają oczywiście przypadki, gdy nieistniejący obiekt, ze względu na swoją wartość artystyczną lub znaczenie ideowe staje się przedmiotem licznych opracowań (na lubelskim gruncie takim przykładem jest zwłaszcza fara św. Michała Archanioła), ale w większości przypadków obiekty niezachowane nie cieszą się szerszym zainteresowaniem badaczy, nawet jeżeli mają oni do dyspozycji szerszą bazę źródłową.

${ }^{3}$ Archiwum Archidiecezjalne Lubelskie (dalej: AAL), Konsystorz Generalny Lubelski, sygn. Rep. 60A 99, Liber visitationum in Archidiaconatu Lublinensi trium decanatuum videlicet Casimiriensis, Parczoviensis, Chodeliensis [1675]; sygn. Rep. 60A 101, Liber visitationis quatuor decanatuum: Chodelienses, Casimiriensis, Parczoviensis, Solecenzis et aliorum in Archidiaconatu Zavichostiensis [1738-1739]; sygn. A 101, Acta visitationis decanatuum: Casimiriensis, Parczoviensis, Chodeliensis et Solecensis archidiaconatus Lublinensis et aliarum in archidiaconatu Zavichostensi ex annis 1736-1739; sygn. Rep. 60A 103, Status ecclesiarum decanatus Parczoviensis et Chodoliensis anno Domini millesimo septingentesimo quadragesiom octavo [1748]; sygn. Rep. 60 A 105, Akta wizyty generalney w trzech dekanatach: chodelskim, urzędowskim y kazimirskim z woli y rozkazu Jaśnie Oświeceonego Imci x. Kajetana Ignacego Sołtyka, biskupa krakowskiego, xiążęcia siewierskiego przez x. Franciszka Dunina Kozickiego, kollegiaty pileckiey dziekana od dnia 15 maja w Roku 1781 poczętej, a w roku 1782 dniach ostatnich miesiąca stycznia odprawioney i dokończoney spisane; sygn. Rep. 60A 182, Actus vistationis generalis decanatus Lublinensis [1800].

${ }^{4}$ Archiwum Kurii Metropolitalnej w Krakowie (dalej: ArKMKr), sygn. AVCap. 65, Compendium actorum visitationis ecclesiarum decanatus Chodeliensis et Parczoviensis, ad archidiaconatum Lublinensem pertinentium, per R.D. Petrum Skidziński, archidiaconum Zawichostensem factae et modo, quo sequitur, conscriptae anno 1611, in Octobre; sygn. AV 6, Acta visitationis interioris archidiaconatus Lublinensis, cuius possessorem tangit ius visitandi in decanatibus: Lucoviensi, Parczoviensi, Chodeliensi, Kazimiriensi et Solecensi, in anno Domini 1617, diebus Iunii et Iulii, opera commissaria R.D. Iacobi Piaseczki, decani Kielcensis, canonici Posnaniensis confecta, k. 30-62; sygn. AV 9, Liber visitationis externae ecclesiarum in decanatu Chodeliensi, per me, Petrum Dobielowicz, decanum Chodeliensem, parochum Opoliensem, commissarium ab R.D. Andrea Trzebicki, episcopo Cracoviensi, duce Severiae, datum et deputatum, conscriptus A.D. 1675; sygn. AV 20, Acta visitationis ecclesiarum archidiaconatus Lublinensis (decanatus: Lucoviensis, Parczoviensis, Casimiriensis, Chodeliensis, civitas Lublinum, decanatus Solecensis) dioecesis Cracoviensis, ex commissione R.D. Constantini Feliciani Szaniawski, episcopi Cracoviensis, ducis Severiae, per R.D. Ioannem Felicem Szaniawski, episcopum Capsensem, suffraganeum, archidiaconum et officialem generalem Leopoliensem, expedita et connotata anno 1721. 
artykule zachowały się w dziewiętnastowiecznych aktach parafii znajdujących się w Archiwum Archidiecezjalnym Lubelskim ${ }^{5}$, a także w aktach Komisji Województwa Lubelskiego i Rządu Gubernialnego Lubelskiego ${ }^{6}$, Gminy Konopnica w Archiwum Państwowym w Lublinie ${ }^{7}$ oraz Archiwum Głównym Akt Dawnych ${ }^{8}$.

Ostatnie lata XIV i pierwsze dekady wieku XV to jeden z okresów szybszego rozwoju sieci parafialnej w archidiakonacie lubelskim ${ }^{9}$ W szczególności widoczne jest to w bezpośrednim zapleczu Lublina, gdzie ukształtowała się wówczas stosunkowo gęsta jak na peryferyjne wówczas jeszcze tereny, siatka instytucji parafialnych. Były to m.in. parafie w Abramowicach ${ }^{10}$, Konopnicy i Zemborzycach $^{11}$, graniczące ze sobą, z ośrodkami odległymi od siebie o ok. $6 \mathrm{~km}$.

Początki parafii w Konopnicy sytuowane są w literaturze przedmiotu na okres między 1374 a 1400 rokiem. Jacek Chachaj wiąże erekcję tej instytucji z Włodkiem z Charbinowic, starostą lubelskim, który w 1386 r. otrzymał Konopnicę od Władysława Jagiełły. W 1400 r., gdy Konopnicę od syna Włodka, Piotra nabywało miasto Lublin, parafia już z pewnością istniała ${ }^{12}$. W wizytacji z $1721 \mathrm{r}$. znajduje się zapis, że wprawdzie nie wiadomo, kiedy parafia została erygowana, ale uposażenie nadane przez radę miasta Lublina zostało spisane w 1428 r., w środę po święcie Bożego Ciała ${ }^{13}$.

Od początku obecności w źródłach parafia nosiła wezwanie św. Katarzyny Aleksandryjskiej, w roku 1565 pojawia się informacja o drugim wezwaniu, św. Małgorzaty ${ }^{14}$ W wizytacji z $1611 \mathrm{r}$. ponownie wskazano wezwanie św. Katarzy-

${ }^{5}$ AAL, sygn. Rep. 60B IVb 84, Fundusze, Budowle, Cmentarze kościoła parafialnego w Konopnicy [1817-1938]; sygn Rep. 60B IVb 85. Akta kościoła parafialnego Konopnica [1882-1896].

${ }^{6}$ Archiwum Państwowe w Lublinie (dalej: APL), Komisja Województwa Lubelskiego i Rząd Gubernialny Lubelski, sygn. 594 I 595.

${ }^{7}$ APL, sygn. 295, Akta Gminy w Konopnicy (z siedzibą w Lublinie).

${ }^{8}$ Archiwum Główne Akt Dawnych (dalej: AGAD), syg. 7841, Prokurator Warszawskiej Izby Sądowej.

${ }^{9}$ J. Chachaj, Bliżej schizmatyków niż Krakowa. Archidiakonat lubelski w XV i XVI wieku, Lublin 2012, s. 77-82.

${ }^{10}$ Powstała zapewne w 1398 roku. Chachaj, Blizej schizmatyków niż Krakowa, s. 264. O parafii w Abramowicach w okresie późniejszym szerzej: A. Hamryszczak, H. Mącik, Parafia i kościoły w Abramowicach w XVII-XIX wieku, „Archiwa, Biblioteki i Muzea Kościelne” (dalej: ABMK), 107 (2017) s. 145-166.

${ }^{11}$ Pierwszy raz wzmiankowana w 1428 r. Chachaj, Bliżej schizmatyków niż Krakowa, s. 299. Szersze opracowanie historii zemborzyckiej parafii i kościołów w artykule: A. Hamryszczak, H. Mącik, Parafia i kościót w Zemborzycach w XVIII-XIX wieku, ABMK, 106 (2016) s. 55-74.

${ }_{12}$ J. Chachaj, Konopnica od XIV do pocz. XVII wieku, w: Weglin, Szerokie, red. H. Mącik, D. Szulc, J. Chachaj, Lublin 2017, s. 10; tenże, Rozwój struktur parafialnych na obszarze Lublina do potowy lat 70. XX wieku, w: Lublin. Historia dzielnic w 700. rocznicę lokacji miasta, red. J. Chachaj, H. Mącik, D. Szulc, Lublin 2017, s. 8-9.

${ }^{13}$ AKMKr, sygn. AV 20, Acta visitationis ecclesiarum archidiaconatus Lublinensis (decanatus: Lucoviensis, Parczoviensis, Casimiriensis, Chodeliensis, civitas Lublinum, decanatus Solecensis) dioecesis Cracoviensis, s. 594.

${ }^{14}$ Chachaj, Bliżej schizmatyków niż Krakowa, s. 279, przypis nr 201. 
ny ${ }^{15}$. W 1675 r. zanotowano jednak, że kościół jest poświęcony tylko Wniebowzięciu Najświętszej Maryi Panny ${ }^{16}$. Taka zmiana patronatu związana była być może ze wzniesieniem murowanego kościoła, w miejsce dotychczasowego drewnianego. Zapewne to wówczas w głównym ołtarzu umieszczono rzeźbioną Pietę. W 1721 r. zanotowano wezwanie Wniebowzięcia NMP i św. Katarzyny ${ }^{17}$. Wtedy też zapisano w protokole wizytacyjnym, że w górnej części ołtarza znajduje się obraz Wniebowzięcia. W kolejnych protokołach $(1736,1748)$ zanotowano tylko wezwanie św. Katarzyny ${ }^{18}$. Natomiast w wizytacji z 1781 r. wspomniano jedynie tytuł Wniebowzięcia NMP ${ }^{19}$.

Pierwotny zasięg parafii konopnickiej jest rekonstruowany przez Jacka Chachaja jako obejmujący trzy położone koło siebie wsie: Konopnicę, Radawiec i Uniszowice. Tak było także później, z tym tylko wyjątkiem, że do parafii włączono powstały w XVI wieku Radawczyk, a z czasem w jej granicach znalazł się także wcześniej należący do parafii lubelskiej Motycz ${ }^{20}$. Parafia w Konopnicy obejmowała w 1611 r. trzy wsie: Konopnica (Konopnicza), Radawiec (Radawiecz), Uniszowice (Unisowiena?) ${ }^{21}$. W 1675 r. do parafii należało pięć wsi: Konopnica, Radawiec, Radawczyk, Uniszowice i Motycz ${ }^{22}$. W XVIII wieku do parafii dołączył Sporniak, przysiółek Radawca ${ }^{23}$, jednak w kolejnym protokole (1748) zabrakło go w wykazie ${ }^{24}$. W wizytacji z 1781 r. do parafii zaliczono sześć wsi:

${ }^{15}$ ArKMKr, sygn. AVCap. 65, Compendium actorum visitationis ecclesiarum decanatus Chodeliensis et Parczoviensis, ad archidiaconatum Lublinensem pertinentium, per R.D. Petrum Skidziński, archidiaconum Zawichostensem factae et modo, quo sequitur, conscriptae anno 1611, in Octobre, k. 538-538v.

${ }^{16}$ AAL, sygn. Rep. 60A 99, Liber visitationum in Archidiaconatu Lublinensi trium decanatuum videlicet Casimiriensis, Parczoviensis, Chodeliensis, k. 167v.

${ }^{17}$ AKMKr, sygn. AV 20, Acta visitationis ecclesiarum archidiaconatus Lublinensis (decanatus: Lucoviensis, Parczoviensis, Casimiriensis, Chodeliensis, civitas Lublinum, decanatus Solecensis) dioecesis Cracoviensis, s. 594.

${ }^{18}$ AAL, Rep. 60A 101, Liber visitationis quatuor decanatuum: Chodelienses, Casimiriensis, Parczoviensis, Solecenzis et aliorum in Archidiaconatu Zavichostiensis, k. 149, 150; AAL, sygn. Rep. 60A 103, Status ecclesiarum decanatus Parczoviensis et Chodoliensis anno Domini millesimo septingentesimo quadragesiom octavo [1748]; k. 206.

${ }^{19}$ AAL, sygn. Rep. 60A 105, Akta wizyty generalney w trzech dekanatach: chodelskim, urzędowskim y kazimirskim z woli y rozkazu Jaśnie Oświeceonego Imci x. Kajetana Ignacego Sołtyka, biskupa krakowskiego, xiążęcia siewierskiego przez x. Franciszka Dunina Kozickiego, kollegiaty pileckiey dziekana od dnia 15 maja w Roku 1781 poczętej, a w roku 1782 dniach ostatnich miesiąca stycznia odprawioney i dokończoney spisane, s. 227.

${ }^{20}$ Chachaj, Bliżej schizmatyków niż Krakowa, s. 279.

${ }^{21}$ ArKMKr, sygn. AVCap. 65, Compendium actorum visitationis ecclesiarum decanatus Chodeliensis et Parczoviensis, ad archidiaconatum Lublinensem, k. 538v.

${ }^{22}$ AAL, sygn. Rep. 60A 99, Liber visitationum in Archidiaconatu Lublinensi trium decanatuum videlicet Casimiriensis, Parczoviensis, Chodeliensis, k. 168.

${ }^{23}$ AAL, Rep. 60A 101, Liber visitationis quatuor decanatuum: Chodelienses, Casimiriensis, Parczoviensis, Solecenzis et aliorum in Archidiaconatu Zavichostiensis, k. 151.

${ }^{24}$ AAL, sygn. Rep 60A 103, Status ecclesiarum decanatus Parczoviensis et Chodoliensis anno Domini millesimo septingentesimo quadragesiom octavo [1748], k. 203v. 
Konopnica, Radawiec, Radawczyk z młynem, Motycz z przysiółkiem Skubicha ${ }^{25}$, Uniszowice (Uniszowiec) oraz Sporniak ${ }^{26}$. Wsie te znajdowały się odpowiednio od kościoła parafialnego: Radawiec (trzy ćwierci mili), Radawczyk (1 mila), Motycz (pół mili), przysiółek Skubicha za Motyczem (pół mili), Uniszowice (1/4 mili), Sporniak (pięć ćwierci mili) ${ }^{27}$. W 2. połowie XIX wieku na obszarze parafii konopnickiej powstały nowe wsie: Tereszyn i Boboszów - obecny Radawczyk Drugi, ale granice parafii nie uległy zmianie do lat międzywojennych, kiedy to powstała nowa parafia w Motyczu. W ostatniej tercji XX stulecia powstały nowe parafie w Radawcu oraz na terenie przyłączonych do Lublina i zurbanizowanych dawnych wschodnich terenów parafii.

Protokoły wizytacyjne informują nas także o liczbie parafian konopnickich, z początku i końca XVIII wieku' ${ }^{28}$. W 1721 r. w parafii w Konopnicy, która obejmowała wówczas pięć wsi, było 1096 wiernych zobligowanych do spowiedzi wielkanocnej czyli mający powyżej siedmiu lat. Wszyscy przystąpili do tego sakramentu i nie było wśród nich żadnych publicznych grzeszników ${ }^{29}$. Według księgi spisu ludności parafii w Konopnicy z 1760 r., liczyła ona wówczas 1354 osób uprawnionych do spowiedzi wielkanocnej ${ }^{30}$. W 1780 r. w parafii w Konopnicy, która obejmowała sześć wsi, ochrzczono 92 dzieci, zmarło 66 osób i udzielono 17 ślubów. Do spowiedzi wielkanocnej w 1781 r. przystąpili wszyscy parafianie $(1350 \text { osób })^{31}$. Mieszkający na terenie parafi byli katolikami ${ }^{32}$. Jednak w spisie ludności z 1787 r.zanotowano, że w Konopnicy żyło 49 Żydów ${ }^{33}$. Ponieważ praca duszpasterska w tej stosunkowo ludnej i rozległej parafii była dużym obciążeniem dla plebana, wizytator wnioskował o zatrudnienie wikariusza. Mogło się to jednak stać dopiero po uzyskaniu zaległej dziesięciny ze wsi Radawiec ${ }^{34}$.

${ }^{25}$ W którym według wizytacji w $1781 \mathrm{r}$. znajdowały się trzy chałupy. AAL, sygn. Rep. 60A 105, Akta wizyty generalney w trzech dekanatach: chodelskim, urzędowskim y kazimirskim, s. 227.

${ }^{26}$ Tamże, s. 226-227.

${ }^{27}$ Tamże, s. 227.

${ }^{28} \mathrm{O}$ różnicach w ilości mieszkańców parafii w różnych źródłach zob. P. Rachwał, Spis ludności parafii Konopnica z 1760 roku, s. 120-121.

${ }^{29}$ AKMKr, sygn. AV 20, Acta visitationis ecclesiarum archidiaconatus Lublinensis (decanatus: Lucoviensis, Parczoviensis, Casimiriensis, Chodeliensis, civitas Lublinum, decanatus Solecensis) dioecesis Cracoviensis, s. 594.

${ }^{30}$ Zob. Rachwał, Spis ludności parafii Konopnica z 1760 roku, s. 120.

${ }^{31} \mathrm{~W}$ dekrecie reformacyjnym, wspomniana jest liczba 1.200 parafian. AAL, sygn. Rep. 60A 105, Akta wizyty generalney w trzech dekanatach: chodelskim, urzędowskim y kazimirskim, s. 232.

${ }^{32}$ Tamże, s. 227.

${ }^{33}$ B. Kumor, Spis ludności diecezji krakowskiej prymasa M.J. Poniatowskiego z 1787 r., ABMK, 35 (1977) s. 265; Rachwał, Spis ludności parafii Konopnica z 1760 roku, s. 120.

${ }^{34}$ AAL, sygn. Rep. 60A 105, Akta wizyty generalney w trzech dekanatach: chodelskim, urzędowskim y kazimirskim, s. 232. 


\section{Konopnickie kościoły}

W historii tego miejsca istniały co najmniej trzy kościoły: najstarszy drewniany, zastąpiony został po $1650 \mathrm{r}^{35}$ murowanym, konsekrowanym w $1667 \mathrm{r}^{36}$, który popadł w ruinę po budowie zachowanego do dziś z lat 1904-1906, wzniesionego na nowym miejscu. $\mathrm{O}$ architekturze pierwszego nie jesteśmy w stanie powiedzieć właściwie nic, ze względu na brak jakichkolwiek szerszych opisów w znanych źródłach, poza tym, że był wzniesiony w całości, razem z zakrystią, z drewna. Drugi kościół doczekał się bardziej obszernych opisów, włącznie z podaniem wymiarów. Znamy także co najmniej jedną fotografię jego ruiny, która daje pewne możliwości rekonstrukcji tego obiektu. Kościół trzeci, istniejący obecnie - jest w pełni zachowany w zasadniczo niezmienionej od czasu budowy formie.

Wcześniejsze świątynie konopnickie znajdowały się w innym miejscu niż obecna. Najstarszy kościół, a po nim kościół murowany z XVII w. stały na terenie niedużego cypla wsuniętego od wschodu w dolinę rzeczki płynącej przez Konopnicę (dziś określanej jako Konopniczanka), na północny zachód od obecnego kościoła, a zarazem po przeciwnej stronie doliny rzeczki od ówczesnego dworu i wsi ${ }^{37}$. Lokalizację tę przekazuje zarówno historyczna kartografia, jak i zachowane do dziś pozostałości starego zespołu kościelnego, w tym ruina dzwonnicy z końca XVIII wieku.

Pierwsze wzmianki o murowanym kościele z zakrystią, który zastąpił drewnianą świątynię pojawiają się w wizytacji z $1675 \mathrm{r}$. Według opisu obiekt był murowany i z cegły (testacinata). Murowana zakrystia była po północnej stronie prezbiterium. Nie wiadomo czy miała ona okna, skoro w protokole zapisano, że była ona bez światła (sed non lucidem). Ogólny stan budynku był niezbyt dobry. W kościele drewniana podłoga była tylko w mniejszym chórze, natomiast w większym znajdowało się klepisko. Dach kościoła był od zewnątrz uszkodzony (rozdarty) przez co murowane sklepienie było zalewane przez deszczówkę. Dodatkowo na strychu kościoła było przechowywane siano oraz zboże w snopach,

${ }^{35}$ Drewniany kościół wspomina w tym miejscu Jan Długosz (Conopnycza. Villa habens in se ecclesiam parochialem ligneam, Sanctae Catherinae dictam..., J. Długosz, Liber beneficiorum dioecesis cracoviensis nunc primum e codice autographo editus, t. 2, wyd. A. Przedziecki, Kraków 1864, s. 539). W wizytacji z roku 1611 podano informację, że kościół wraz z zakrystią są drewniane. Zob. ArKMKr, sygn. AVCap. 65, Compendium actorum visitationis ecclesiarum decanatus Chodeliensis et Parczoviensis, ad archidiaconatum Lublinensem, k. 538-538v. Potwierdzono ten stan również w 1650 r., AAL, sygn. A 97, Visitatio ecclesiarum in Archidiaconatu Lublinensi [1644, 1650], k. 38r. Nie mamy ze względu na brak źródeł pewności, że kościół wzmiankowany przez Długosza i te wskazane w latach 1611 i 1650 to ten sam obiekt, ale jest to możliwe.

${ }^{36}$ Taką datę konsekracji podano w wizytacji z roku 1781, AAL, Rep. 60A 105, Akta wizyty generalney w trzech dekanatach: chodelskim, urzędowskim y kazimirskim, s. 227. Kościół murowany wspominano już wizytacji z roku 1675, AAL, Rep. 60A 99, Liber visitationum in Archidiaconatu Lublinensi trium decanatuum videlicet Casimiriensis, Parczoviensis, Chodeliensis, k. 166r.

${ }^{37}$ Osiemnastowieczną, zapewne kontynuująca średniowieczną, lokalizację dworu i folwarku, inną niż późniejsza dworu z XIX wieku, po podziale Konopnicy, ukazuje m.in. tzw. Mapa Heldensfelda $z$ lat 1801-1804, zachowana w Kriegsarchiv Wien, dostępna on-line: https://mapire.eu/en/map/ europe-18century-firstsurvey/ (dostęp: 10.09.2019). 
ponieważ nie było stodoły ani stajni. Okna w kościele były potłuczone i przykryte słomą. Kościół miał również drewniany okap (porticus) pod którym stał wóz oraz sochy (pługi) i radła. Dodatkowo w samym wnętrzu kościoła przechowywano 18 starych skrzyń. Nie było w nim natomiast ławek. W kościele były trzy konsekrowane ołtarze: pozłacany wielki z rzeźbą Matki Bożej Bolesnej, od strony północnej Wszystkich Świętych, zaś św. Katarzyny od południa. Ambona była drewniana, nie malowana. W dzwonnicy, pozbawionej dachu i ścian, umieszczone były dwa dzwony: duży i mały. Cmentarz, określony jako nędzny (vile), był ogrodzony zwartymi krzakami (virgultos) i był pełny gnoju (sterconibus), rozkopany przez świnie ${ }^{38}$. Podsumowując stan opisywanego kościoła wizytator stwierdził, że nigdzie nie można w nim zobaczyć czystości, nawet mens ołtarzowych, a wszędzie jest brud i pajęczyny ${ }^{39}$. Jest dość zdumiewające, że zaledwie kilka lat po zakończeniu budowy kościoła (gdyby budowa nie była ukończona nie można byłoby świątyni konsekrować) budynek był w tak złym stanie.

Murowany kościół w Konopnicy, ze względu na prostotę formy i stosunkowo przysadziste proporcje, już kilka dekad po budowie budził mieszane uczucia odbiorców, wizytator w 1738 r. użył do jego opisu specyficznych określeń: „Basilica murata sed ex lapide simplici vulgo opere ades est debilis (...)”. Cmentarz przykościelny był wówczas ogrodzony nowym parkanem z drewna dębowego ${ }^{40}$. Przyczyną problemów był, jak można przypuszczać, stan techniczny kościoła, zbudowanego nad doliną, być może niedostatecznie fundamentowanego. Jeszcze w 1721 r. wizytator opisywał kościół jako przekryty ceglanym sklepieniem, oceniał go jako stosunkowo nowy, chociaż podawał błędnie wiek obiektu. Jednocześnie zauważał zły stan ścian kościoła mimo jego stosunkowo młodego wieku ${ }^{41}$.

Po raz pierwszy szerzej opisana została wówczas zakrystia, która znajdowała się obok małego chóru, od strony Ewangelii ${ }^{42}$ wielkiego ołtarza. Był to obiekt

${ }^{38}$ AAL, sygn. Rep. 60A 99, Liber visitationum in Archidiaconatu Lublinensi trium decanatuum videlicet Casimiriensis, Parczoviensis, Chodeliensis, k. 167v; ArKMKr, sygn. AV 9, Liber visitationis externae ecclesiarum in decanatu Chodeliensi, per me, Petrum Dobielowicz, decanum Chodeliensem, parochum Opoliensem, commissarium ab R.D. Andrea Trzebicki, episcopo Cracoviensi, duce Severiae, datum et deputatum, conscriptus A.D. 1675, k. 51v-52.

39 „In Ecclesia nullam munditiam reperimus, altarium mensas, sordibus talisque araneis plenissimas conspeximus". AAL, sygn. Rep. 60A 99, Liber visitationum in Archidiaconatu Lublinensi trium decanatuum videlicet Casimiriensis, Parczoviensis, Chodeliensis, k. 167v; ArKMKr, sygn. AV 9, Liber visitationis externae ecclesiarum in decanatu Chodeliensi, k. 52.

${ }^{40}$ AAL, Rep. 60A 101, Liber visitationis quatuor decanatuum: Chodelienses, Casimiriensis, Parczoviensis, Solecenzis et aliorum in Archidiaconatu Zavichostiensis, s. 149.

${ }^{41}$ „Ecclesia ipsa est (...) ante annos 40. noviter de lateribus extructa, lateribus concamerata, sed parietes eius ruinas spirant. Tectum in eo apparet suisse de tegulis ligneis, sed nunc vix tectum dici potest. Pavimentum in ea ex asseribus, fenestrae numero 10. bonae. Copula super tectum Ecclesiae tramineum est lignea bona cum cruce, continet in se campanulam parvam nescitur an benedictam. Ianua ad Ecclesiam una bene clausa (...)", AKMKr, sygn. AV 20, Acta visitationis ecclesiarum archidiaconatus Lublinensis (decanatus: Lucoviensis, Parczoviensis, Casimiriensis, Chodeliensis, civitas Lublinum, decanatus Solecensis) dioecesis Cracoviensis s. 594.

${ }^{42}$ Lewa strona ołtarza. Przed Soborem Watykańskim II, kapłan z tej strony odczytywał Ewangelię. B. Nadolski, Orientacja (Conversi ad Dominum), w: Leksykon liturgii, red. B. Nadolski, Poznań 2006, s. 1132. 
murowany, z ceglanym sklepieniem i pobielony wapnem. Zakrystia miała drzwi drewniane, dobrze zamknięte oraz dwa okna, z których jedno posiadało żelazną kratę. W środku znajdował się drewniany stół z czterema szufladami, a nad nim szafa zamykana do przechowywania Najświętszego Sakramentu ${ }^{43}$. W kościele był również ceglany chór organowy, w którym znajdował się mały pozytyw szkatulny, potrzebujący reparacji ${ }^{44}$.

Od poprzedniej wizytacji do 1721 r. przybyło wyposażenia w kościele, poczyniono też drobne remonty. Sprawiony został nowy drewniany ołtarz św. Katarzyny, który nie był jeszcze nawet pomalowany. Natomiast ołtarz Wszystkich Świętych był uszkodzony (diametrio), nie wspomniano jednak o charakterze tych zniszczeń. W wielkim ołtarzu, wykonanym z drewna i pozłoconym, w centralnej części znajdowała się rzeźbiona łaskami słynąca Pieta, a w górze obraz Wniebowzięcia NMP. Przybyło również 11 obrazów różnych świętych, zawieszonych na ścianach kościoła. Po stronie północnej stała drewniana chrzcielnica, być może przy ołtarzu Wszystkich Świętych ${ }^{45}$. Pomalowana została drewniana ambona ${ }^{46}$, dotychczas bez malatury. W kościele znajdował się również jeden konfesjonał oraz jedna drewniana ławka, bez malatury, do której przymocowano sześć starych małych chorągwi oraz jedną dużą ${ }^{47}$.

Zły stan techniczny kościoła został stwierdzony również w 1738 r. Poczynione zostały wówczas jednak pewne prace remontowe. Część ceglanego sklepienia kościoła, które było zalewane przez deszczówkę z powodu zniszczonego dachu, została rozebrana. W to miejsce zbudowano sufit $\mathrm{z}$ desek (ex asseribus). W związku z tymi pracami, naprawiono dach wymieniając zniszczone klepki z gontu na dachówki (extegulis). Umieszczono wówczas sygnaturkę z małym dzwonem, w połowie długości dachu kościoła. Naprawy wymagały jednak okna w kościele, których było siedem, o trzy mniej w stosunku do poprzedniego opisu z $1721 \mathrm{r}$. (być może je zamurowano lub zamknięto czasowo w inny sposób). Dobre były natomiast dwa okna w zakrystii, w tym jedno z kratą żelazną. Nie wymagała naprawy drewniana podłoga $\mathrm{w}$ kościele, ani w zakrystii, gdzie zaznaczono, że jest ona $\mathrm{z}$ drewna dębowego. Dodatkowo na posadzce od dużego ołtarza zaścielone było czerwone sukno, składające się z kilku starszych fragmentów. Do kościoła było tylko jedno wejście od strony północnej, dobrze zamknięte zamkiem żelaznym. Wizytacja przynosi również informację o znajdujących się w kościele dwóch kryptach murowanych, do których wejście było wewnątrz świątyni. Mia-

${ }^{43}$ AKMKr, sygn. AV 20, Acta visitationis ecclesiarum archidiaconatus Lublinensis (decanatus: Lucoviensis, Parczoviensis, Casimiriensis, Chodeliensis, civitas Lublinum, decanatus Solecensis) dioecesis Cracoviensis, s. 591.

${ }^{44}$ Tamże, s. 594.

${ }^{45}$ Tamże, s. 591.

${ }^{46} \mathrm{~W}$ wizytacji z 1736 r. podano, że ambona ma kolor czerwony. AAL, sygn. Rep. 60A 101, Liber visitationis quatuor decanatuum: Chodelienses, Casimiriensis, Parczoviensis, Solecenzis et aliorum in Archidiaconatu Zavichostiensis, k. 150.

${ }^{47}$ AKMKr, sygn. AV 20, Acta visitationis ecclesiarum archidiaconatus Lublinensis (decanatus: Lucoviensis, Parczoviensis, Casimiriensis, Chodeliensis, civitas Lublinum, decanatus Solecensis) dioecesis Cracoviensis, s. 593-594. 
ły one trzy szyby odpowietrzające. Cmentarz był tylko częściowo ogrodzony. W części ogrodzonej były dwie bramy: jedna od północy, a druga od wschodu ${ }^{48}$.

We wspomnianym 1738 r. zauważyć można również poprawę wyposażenia kościoła. Stare organy szkatulne wymieniono na organy gdańskie, których stan określono jako dobry. Były również dwie ławki. Ambona, umiejscowiona w części północnej kościoła została pomalowana na czerwono. Wybudowano również od południa nowy drewniany ołtarz św. Katarzyny, który był rzeźbiony i posrebrzany. W kościele umieszczono również pod sufitem belkę tęczową z drewnianym krzyżem i rzeźbami Matki Bożej i św. Jana ${ }^{49}$.

Jednak pomimo przeprowadzenia remontów w świątyni dziesięć lat wcześniej, już w 1748 r. stan kościoła w Konopnicy był niezadowalający. Wynikało to chyba ze zbyt dużej skali zniszczeń oraz niewystarczających środków finansowych do przeprowadzenia generalnego remontu świątyni. Według świadectwa plebana, ks. Jan Stargowskiego, kiedy obejmował parafię, zastał kościół i plebanię jako „rudery”. Jak twierdził, taki stan wynikał ze zubożenia parafii oraz częstej rezygnacji plebanów $z$ tego beneficjum ${ }^{50}$. Prace remontowe podejmowane przez J. Stargowskiego były więc bardzo rozległe. W 1748 r. zanotowano, że wybudowany został nowy wielki ołtarz ${ }^{51}$ oraz ołtarz św. Katarzyny. Wstawiono nową więźbę dachową, gdyż dotychczasowa zgniła. W zakrystii wstawiono podłogę oraz nowe okna w kościele. Prace te kosztowały 2.800 zł. Ołtarz Św. Trójcy własnym sumptem sprawił wcześniej kolator kościoła Marcin Trębiński ${ }^{52}$.

Sklepienie ${ }^{53}$ kościoła w dużym chórze, które było „pogruchotane” zostało rozebrane, a w to miejsce wstawione zostały smolne bale sosnowe ${ }^{54}$. Łączny koszt tych prac wyniósł $300 \mathrm{zł}$ bez zapłaty za robociznę rzemieślnikom ${ }^{55}$. Ponadto pleban naprawił parkany na cmentarzu ${ }^{56}$. Również zreperował dzwonnicę i dach kościoła, który w większej części był zniszczony. Materiały na naprawę kosztowały 100 zł. Pleban zamówił również wykonanie nowej ambony ponieważ dotychcza-

${ }^{48}$ AAL, sygn. Rep. 60A 101, Liber visitationis quatuor decanatuum: Chodelienses, Casimiriensis, Parczoviensis, Solecenzis et aliorum in Archidiaconatu Zavichostiensis, k. 149v.

${ }^{49}$ Tamże, k. 150.

${ }^{50}$ „Kościół zastałem y Plebanią iedyne rudera bo zadney konserwacyey in antecessum tak ab extra iako ab intra koscioł nie miał dla zubożenia y czestey resignacyey antecedaneorum przedemną których pięciu resignowało". AAL, sygn. Rep 60A 103, Status ecclesiarum decanatus Parczoviensis et Chodoliensis anno Domini millesimo septingentesimo quadragesiom octavo [1748], k. 205v-206.

${ }^{51}$ Drewniany ołtarz główny był posrebrzany. Umieszczona w nim była Pieta. Tamże, k. 202v.

${ }^{52}$ Marcin Trębiński (Trębinski) był chorążym lubelskim (1726-1733). Zob. Urzędnicy województwa lubelskiego XVI-XVIII wieku, red. A. Gąsiorowski, oprac. W. Kiełczewski, W. Urban, Kórnik 1991, s. 19, 130. W 1748 r., podczas spisywania wizytacji Trębiński nie żył.

${ }^{53} \mathrm{~W}$ kościele był, jak opisano wizytacji z 1738 r., sufit z drewna, jednak przy wielkim chórze było sklepienie ceglane. $Z$ powodu jednak niebezpieczeństwa zawalenia, zostało ono usunięte. Tamże, k. 202v.

${ }^{54}$ Bale były przygotowane w miejscowości znajdującej się o trzy mile od Konopnicy.

${ }^{55}$ Tamże, k. 206.

${ }^{56}$ Ogrodzenie cmentarza wykonane było $\mathrm{z}$ drewna dębowego, jednak nie obejmowało ono całego terenu. Postała część dotychczasowego ogrodzenia rozpadała się. Tamże, k. 202v. 
sowa „bardziey szpeci niż zdobi”. Dopiero po jej wysrebrzeniu miała być umieszczona w kościele ${ }^{57}$.

W świątyni należało wykonać jeszcze sklepienie i pilastry, tak jak w dużym chórze. Koszty materiału na ten cel i robocizny pleban szacował na $450 \mathrm{złp}^{58}$.

Należy zauważyć również, że w kościele zanotowano istnienie trzech sklepionych krypt murowanych, z czterema szybami odpowietrzającymi, co sugeruje kolejny pochówek $\mathrm{w}$ świątyni. Zanotowano również, że w kościele było 8 okien, o jedno więcej niż w 1738 r., oraz dwa w zakrystii. Wszystkie były wymienione przez aktualnego plebana. Również organy gdańskie na chórze nie były zepsute ${ }^{59}$.

Dostrzec możemy także, że północny ołtarz dotychczas poświęcony Wszystkim Świętym, został zastąpiony nowym, pod wezwaniem Trójcy Świętej. Był on z fundacji właścicieli Konopnicy Marcina i Heleny Trębińskich. Obraz Trójcy Świętej był określony jako znakomity dawnego malarstwa (excelentis antiquae picturae $)^{60}$.

W roku 1760 poddano kościół remontowi, co opisano w wizytacji z 1781 r.:

Kościół wraz z zakrystyą iest $\mathrm{z}$ opoki murowany sub titulo Assumptionis B[aeate] V[irginis] Mariae. Konsekrowany Anno 1667 ab Illustrimo Nicolas Oborski (...) Kościół reparowany w roku 1760 ex sola iest wytrynkowany, Facyatą, Kopułą białą pobitą blachą, suffitem adornowany, dachem pokryty $(\ldots)^{61}$.

Zapewne w trakcie tegoż remontu z 1760 r. zlikwidowano pozostałą część ceglanego sklepienia wnętrza kościoła (oprócz zakrystii) i zastąpiono go nisko osadzonym stropem $z$ sufitem ${ }^{62}$, nie zbudowano nowego sklepienia, które planowano w 1748 r. Przyjęcie takiej chronologii przekształceń kościoła wynika z jednej strony z porównania opisów wizytacyjnych, z drugiej zaś z analizy zachowanej fotografii ruiny kościoła $\mathrm{z}$ lat 20 . XX w., na której widoczne są dolne partie zniszczonego sklepienia, w tym lunety ponad oknami nawy, a jednocześnie gniazda belek stropowych, umieszczone poniżej lunet, wykute w tynkowanej ścianie - co wskazuje na ich wtórny charakter. Taki zakres remontu potwierdza częściowo zachowany wykaz wydatków na remonty kościoła w latach 1759-1779, zawarty na ostatnich kartach księgi zgonów konopnickiej parafii z lat 1759-1811 ${ }^{63}$. „Kopułę”

${ }^{57}$ Tamże, k. 206-206v.

${ }^{58}$ Tamże, k. 206v.

${ }^{59}$ Tamże, k. 202v, 203.

${ }^{60}$ Tamże, k. 203.

${ }^{61}$ AAL, Rep. 60A 105, Akta wizyty generalney w trzech dekanatach: chodelskim, urzędowskim y kazimirskim, s. 227. W tym miejscu wypada zaznaczyć, że datę konsekracji kościoła, dotychczas podawano w różnych opracowaniach oraz na stronach internetowych błędnie jako rok 1662, zamiast 1667, co było wynikiem nieprawidłowego odczytania daty podanej w wizytacji z $1781 \mathrm{r}$.

${ }^{62}$ Niewykluczone, że wówczas także obniżono cały kościół, bowiem istniejące wcześniej sklepienie wymagać mogło wyższych ścian.

${ }^{63}$ O księdze szerzej: P. Rachwał, Spis ludności parafii Konopnica z 1760 roku, „Przeszłość Demograficzna Polski”, 38 (2016) nr 2, s. 117-133. Księga dostępna on-line w serwisie internetowym www.ksiegimetrykalne.pl. (dostęp: 10.09.2019). 
czyli wieżyczkę na sygnaturkę na dachu kościoła wykonano zapewne na nowo w $1763 r^{64}$

Przy kościele stała drewniana dzwonnica, która według opisu z 1675 r. nie mała dachu i ścian (konstrukcja słupowa?). Wisiały na niej dwa dzwony: duży i miały. Obok była drewniana kostnica (ossorium) ${ }^{65}$. W 1721 r. dzwonnica była zlokalizowana tuż obok wejścia kościoła i łączyła się z nim ${ }^{66}$. W 1738 r. naprawiano dzwonnicę, w której były dwa duże dzwony, jednak nie była ona już pod wspólnym dachem z kościołem ${ }^{67}$. Remont obiektu opóźniał się albo był pobieżny, skoro w 1748 r. zanotowano że dzwonnica jest zniszczona i teraźniejszy pleban czuwa nad jej stanem. Stwierdzono również, że znajdują się w niej dwa dzwony: duży i mały, nie konsekrowany, co może wskazywać na jego niedawne zawieszenie $^{68}$. W 1781 r. tak opisano obiekt:

(...) dzwonnica na ośmiu słupach, tarcicami obita, z gzemsami y dachem, troie drzwi maiąca, w iednych zamek ryty, u wszystkich zawiasy żelazne. Dzwonow w niey dwa, ieden pomiernie wielki, drugi mały ${ }^{69}$.

Między 1781 a 1800 rokiem wybudowano po zachodniej stronie cmentarza kościelnego, nad doliną rzeczki, od dojazdu ze wsi do kościoła, nowszą dzwonnicę murowaną, zachowaną do dziś w ruinie oraz murowane ogrodzenie cmentarza kościelnego.

W 1800 r. kościół opisano najbardziej szczegółowo, jako obiekt murowany, orientowany, z fasada zwróconą na zachód. Jego rozmiary wynosiły 10 sążni długości i 4 sążnie szerokości. Dach był kryty dachówką, zaś wieżyczka na sygnaturkę białą blachą, zarówno przekrycie dachu, jak i wieżyczki wymagało naprawy. Posadzka w kościele była kamienna, zaś drewniany chór muzyczny był wsparty na dwóch drewnianych kolumnach, pod nim stały trzy konfesjonały. Po stronie Ewangelii znajdowała się malowana ambona i chrzcielnica „,dawnej struktury”. Wnętrze kościoła oświetlało osiem okien. Krypty pod kościołem opisano

Niestety w zapisach wydatków nie wskazano dokładnie zakresu prac, ograniczono się do opisu charakteru ekspensu (mularzowi, pomocnikom etc.) oraz kwot wydanych na prace. Interesujące jest podanie nazwisk wykonawców prac. Wiemy dzięki temu, że w latach 1759-1761 prowadził te prace murarz Szymon Kozłowski.

${ }^{64}$ Tamże. Prace ciesielskie (określone jako stolarskie) prowadził Marcin Wojciechowski, zaś złotnicze (pozłocenie krzyża i ,gałki” na wieżyczce) Zarzecki.

${ }^{65}$ AAL, sygn. Rep. 60A 99, Liber visitationum in Archidiaconatu Lublinensi trium decanatuum videlicet Casimiriensis, Parczoviensis, Chodeliensis, k. 167v.

${ }^{66}$ „Campanile est ligneum vetustum, indigens reparatione, cum tecto suo, quod nunc est stramineum, Hoc Campanile est iunctum Ecclesiae ad ianuam eius situm, continens duas campanas mediocres nescitur an benedictas". AKMKr, sygn. AV 20, Acta visitationis ecclesiarum archidiaconatus Lublinensis (decanatus: Lucoviensis, Parczoviensis, Casimiriensis, Chodeliensis, civitas Lublinum, decanatus Solecensis) dioecesis Cracoviensis s. 594.

${ }^{67}$ AAL, sygn. Rep. 60A 101, Liber visitationis quatuor decanatuum: Chodelienses, Casimiriensis, Parczoviensis, Solecenzis et aliorum in Archidiaconatu Zavichostiensis, k. 149v.

${ }^{68}$ AAL, sygn. Rep 60A 103, Status ecclesiarum decanatus Parczoviensis et Chodoliensis anno Domini millesimo septingentesimo quadragesiom octavo [1748], k. $202 \mathrm{v}$.

${ }^{69}$ AAL, sygn. Rep. 60A 182, Actus civitationis generalis decanatus Lublinensis, s. 227. 
wówczas dwie - być może trzecia, wymieniona we wcześniejszych opisach była wówczas niedostępna. W obu grobowcach nie było wtedy pochówków. Zakrystia miała dwa okna, z czego jedno było zamknięte żelazną kratą ${ }^{70}$. Wewnątrz kościoła znajdowały się trzy ołtarze: „Altare maius veteris structurae vario depictum colore in quo est lignea statua gloriosissima V. Maria dolorosa (...)" oraz dwa boczne - Św. Trójcy i św. Katarzyny ${ }^{71}$.

Po raz pierwszy opisano wówczas murowaną dzwonnicę, zachowaną w ruinie do dziś. Podano jej wymiary (2 1/2 na $21 / 3$ sążnia), oraz wskazano, że są w niej dwa dzwony - większy i mniejszy. Cmentarz przykościelny miał wówczas rozmiary 20 na 19 sążni i był otoczony murem ${ }^{72}$.

Stan kościoła niemal identyczny jak w 1800 r. ukazuje opis z roku 1817 , włącznie z powtórzonymi rozmiarami kościoła (ma dlugość sążni 10, a szerokości sążni 4). Różnicą jest „babiniec” (kruchta) od strony zachodniej ,z trzema wychodami”, które zapewniały dojście do frontowych drzwi kościoła wiernym przychodzącym z różnych części parafii, z trzech kierunków. Stan kościoła był wówczas dobry, choć zaznaczono, że gontowe pokrycie dachu wymaga częściowo naprawy. ${ }^{73}$ Kolejnego remontu świątyni dokonano w $1839 \mathrm{r}^{74}$

Kościół ten funkcjonował do czasu budowy nowego, zlokalizowanego na wschód od starego, przy wytrasowanej kilka dekad wcześniej nowej drodze - tzw. szosie kraśnickiej. Podobnie, jak w wielu innych przypadkach tego rodzaju na Lubelszczyźnie powodem dążenia do wystawienia nowej świątyni był wzrost liczby mieszkańców parafii, dla której stary kościół stał się zbyt mały, a jego specyficzna lokalizacja, na cyplu wsuniętym $\mathrm{w}$ dolinę rzeczki uniemożliwiała rozbudowę. Po przeniesieniu nabożeństw do nowej świątyni konopniccy parafianie zamierzali

${ }^{70}$ „Ecclesia hac de muro extructa, maiori altari ad orientem, faciata ad occidentem posita. Longitudinis 10., latudinis 4. orgiarum. Pavimentum lapidibus stratum, tectum scandulis, turriculalamine albo cooperta, aliqua ex parte omnia indigaent reparatione. Fores ad ecclesiam dispartita, canilinbus(?) ferreis suffulcris et claustro provisa. Supra has in aditu ecclesia est chorus ligneis duabus columnis ligneis firmatus, ad quem gradus ex aperibus. In eo organum. In angulis sub choro duo scamna ab utriumque, a maioris altare tertium posita. Confesionalia lignea, sine cratibus, ad parietes in facie ecclesia posita 3. A parte Evangelii ambona lignea vetus colore caules depicta. Ex opposito eiusdem baptisterium veteris structura. Fenestra octo omnes reparanda. Tumuli murati duo, in quibus ad praesens corpora non sepeliuntur. A cornu Evangelii sacristia murata, fores ad eam ex ecclesia cardinibus, claustro ac retinaculo provisa. Fenestra in ea dua, una cum cratibus ferreis munita. In sacristia armarium per modum mensa pro conservanda supellectili ecclesiastica; tamże", s. 271.

${ }^{71}$ Tamże, s. 272.

72 „Campanile ex opposito ecclesia versus occidentem longitudinis orgiarum 2 1/2 latitudinis $21 / 3$ cortineus campanas 2 . maiorem et minorem. Coemeterium longitudinis orgiarum 20. Latitudis 19 muro septum bene claususum in quo cadavera usque adhuc sepelientur ab non septum extra villam locum". tamże.

${ }^{73}$ AAL, sygn. Rep. 60B IVb 84, Fundusze, Budowle, Cmentarze kościoła parafialnego w Konopnicy, brak pag.

${ }^{74}$ Tamże, k. 12-27 - na tych kartach m.in. szczegółowy opis kościoła innych zabudowań i majątku parafii z 5/17 czerwca 1842 r. Kolejny opis, w dużym stopniu powtarzający poprzednie, wykonano w 1852 r., tamże, k. 28-44, odpis w: APL, Komisja Województwa Lubelskiego i Rząd Gubernialny Lubelski, sygn. 594, brak paginacji. 
stary kościół wykorzystać jako salę zebrań parafialnych. Z pismem o pozwolenie na takie działania zarząd Związku Katolickiego parafii Konopnica wystąpił do biskupa lubelskiego 29 marca $1908 \mathrm{r}$. Warunkiem pozwolenia miało być usunięcie emblematów kościelnych z budynku, by jego już nie sakralna funkcja była jasna ${ }^{75}$. Zgodę biskupa konopniccy parafianie otrzymali, niestety, po wzniesieniu nowego kościoła stary dość szybko popadł w ruinę i jeszcze w okresie międzywojennym przestał istnieć. Do dziś zachowały się na terenie dawnego cmentarza kościelnego ruiny dzwonnicy, relikty murów ogrodzeniowych oraz słabo czytelne pozostałości kościoła. Można zakładać, że zachowane są także grobowce, których istnienie pod kościołem wskazywano w wizytacjach z XVIII stulecia.

Pozostałości starej świątyni nie zostały dotąd przebadane archeologicznie, chociaż czytelne częściowo fundamenty wskazują, że za pomocą badań, choćby nieinwazyjnych, możliwe byłoby szczegółowe określenie jego rzutu, a także zlokalizowanie wzmiankowanych w źródłach krypt grobowych. Opisy oraz fotografia ruiny kościoła, pochodząca $\mathrm{z}$ lat 20 . XX w. dają możliwości jego rekonstrukcji. Kościół był orientowany, fasadą skierowany na zachód, w kierunku Konopniczanki i zabudowań wsi po jej drugiej stronie. Był to stosunkowo nieduży $(10 \times 4$ sążnie - według opisów z lat 1800 i 1817, czyli ok. 17,8×7,1 m, licząc wg miary sążnia staropolskiego według konstytucji sejmowej z 1764 r.), murowany kościół. Był jednonawowy, z węższym od nawy prezbiterium, zapewne zamkniętym trójbocznie. Nawa była trójprzęsłowa, prezbiterium musiało być znacznie krótsze od niej, zapewne jednoprzęsłowe. W nawie i prezbiterium według opisów z lat 1800 i 1817 było łącznie osiem okien. Jak wskazuje fotografia ruiny kościoła $\mathrm{z}$ okresu międzywojennego, sześć $\mathrm{z}$ nich było $\mathrm{w}$ nawie $-\mathrm{w}$ jej ścianach bocznych, jedno ponad chórem muzycznym - w fasadzie zachodniej kościoła (te okna są widoczne na fotografii), a ostatnie - ósme, zapewne w prezbiterium. Chór kapłański i nawa początkowo były sklepione, później - po rozbiórce sklepienia, przekryte były stropami. Do prezbiterium od północy przylegała sklepiona zakrystia z dwoma oknami, skomunikowana z kościołem drzwiami.

Czas powstania, jak i forma architektoniczna kościoła sytuują go w grupie realizacji wiązanych z lubelskim środowiskiem muratorów cechowych, ich pokolenia czynnego w 3 ćw. XVII wieku. Nie dysponujemy niestety żadnymi informacjami, które mogłyby wskazać, który konkretnie murator był projektantem i wykonawcą tej świątyni. Przede wszystkim stary kościół konopnicki wykazuje bliskie podobieństwa $\mathrm{z}$ dwiema zachowanymi budowlami ze zbliżonego okresu: dawnym lubelskim kościołem reformatów pw. św. Kazimierza (z lat 1663-1674) ${ }^{76}$ oraz kościołem parafialnym w Popkowicach, zbudowanym w latach 60. XVII stulecia, konsekrowanym w $1667 \mathrm{r}^{77}$ Wszystkie trzy wymienione świątynie mają

${ }^{75}$ Tamże.

${ }^{76}$ Szerzej o lubelskim kościele reformatów E. Szczęch, Dawny kościót reformatów - obecnie browar-Dabrowskiego 15 w Lublinie, Lublin 1973, mps, Archiwum WUOZ Lublin oraz M. Trzewik, Klasztor reformatów w Lublinie, w: Druga szansa zakładów przemysłowych Vetter w Lublinie, red. K. Czerlunczakiewicz, H. Mącik, M. Trzewik, Lublin 2018, s. 15-36.

${ }^{77} \mathrm{O}$ historii tego obiektu: A.U. Wnuk, Dzieje parafii Popkowice: 600 lat historii, Urzędów 2004. Kościół popkowicki został rozbudowany pod koniec XIX w., jednak bryła zachowała zasadnicze cechy z okresu budowy. 
analogiczny układ przestrzenny: jednonawowy z węższym i niższym prezbiterium zamkniętym trójbocznie. Wymiary kościoła konopnickiego podawane w cytowanych wyżej opisach dają możliwość określenia proporcji kościoła, które są tożsame jak w przypadku kościoła św. Kazimierza w Lublinie, przy nieco innej skali budowli - kościół lubelski jest większy. Z kolei kościół popkowicki, ma nie tylko zbliżone proporcje, ale także bardzo podobne rozmiary do nieistniejącego kościoła konopnickiego. Zarówno kościół konopnicki, jak i popkowicki mają dość ograniczone cechy, które moglibyśmy powiązać z konkretnymi stylami architektonicznymi. Były to budowle proste, o skromnym detalu, przy czym należy zaznaczyć, że w obu przypadkach nie dysponujemy pełną wiedzą o ich pierwotnym wyglądzie. Zarówno wygląd wnętrza kościoła konopnickiego na znanym nam zdjęciu archiwalnym, jak i obecny stan świątyni w Popkowicach, są wynikami wielokrotnych remontów i przekształceń tych obiektów.

Nowy kościół konopnicki zbudowany został w latach 1904-1905, według projektu lubelskiego architekta Władysława Sienickiego ${ }^{78}$, a konsekrowany w 1906 r. przez bpa Franciszka Jaczewskiego. Zachowana do dziś świątynia to budowla murowana, wzniesiona na planie krzyża łacińskiego, trójnawowa z transeptem i zamkniętym trójbocznie prezbiterium, z wieżą w fasadzie zachodniej.

Architektura kościoła, wbrew informacjom dostępnym w internecie i starszych przewodnikach, nie jest neogotycka. To swoisty, nierzadki w tym okresie na ziemiach polskich, choć rzadki na zdominowanej przez neogotyckie formy architektury kościelnej Lubelszczyźnie ${ }^{79}$, ciekawie skomponowany, eklektyczny konglomerat form romanizujących (w elewacjach zewnętrznych kościoła) i inspirowanych architekturą renesansową (wewnątrz). W stylistyce neorenesansowej utrzymano także wyposażenie wnętrza, pochodzące zasadniczo z okresu budowy kościoła, za wyjątkiem głównego ołtarza, którego forma powtarza co prawda kształt pierwotnego, z 1906 r., ale który został wykonany na nowo, po pożarze, w 1971 r., przez M. Pudełko i E. Ścibora - nauczycieli nałęczowskiego liceum plastycznego. Z okresu powojennego pochodzą także witraże (1957) oraz polichromia wnętrza (1979).

${ }^{78} \mathrm{~W}$ Archiwum Państwowym w Lublinie zachowały się dokumenty świadczące o pracach projektowych Sienickiego dla Konopnicy. W aktach Gminy w Konopnicy zachowała się jednostka opisana jako „Plan i kosztorys kościoła oraz plan szkoły w Konopnicy”, pochodząca z 1900 r. W niej znajdują się na kilku kartach, wraz z przekrojami, szczegółowe obliczenia konstrukcyjne dla planowanego kościoła, podpisane przez Władysława Sienickiego. Oczywiście jest możliwe, aby W. Sienicki wykonał obliczenia konstrukcyjne dla innego architekta, jednak biorąc pod uwagę jego kompleksową działalność oraz formy konopnickiego kościoła, bliskie innym jego pracom, zasadne jest założenie, że był także projektantem architektury tego obiektu. APL, Akta Gminy w Konopnicy (z siedzibą w Lublinie), sygn. 295. Projekty samego kościoła być może zaginęły wraz z zagubionymi przez jednego z kolatorów kościoła, architekta Włodzimierza Wołłodkę innymi dokumentami dotyczącymi budowy. Archiwum Główne Akt Dawnych, Prokurator Warszawskiej Izby Sądowej, sygn. 7841.

${ }^{79}$ Szerokie omówienie przyczyn popularności neogotyku w regionie w pracy J. Żywicki, Architektura neogotycka na Lubelszczyźnie, Lublin 1998. 
Władysław Sienicki ${ }^{80}$ stosował w swojej pracy - zgodnie z duchem epoki - różnorodne formy architektury historycznej. Są wśród nich zarówno dość doktrynalne, jak można dziś powiedzieć naśladowania form gotyckich (kościół we Frampolu), renesansowych (gmach Towarzystwa Kredytowego Miejskiego w Lublinie przy ul. Ogrodowej, rozbudowa kościoła w Czerniejowie czy kamienica przy ul. Ogrodowej $10 \mathrm{w}$ Lublinie) oraz barokowych (nowe skrzydło gmachu seminarium duchownego w Lublinie), jak również swobodniejsze formalnie projekty secesyjne (hala fabryczna w Zakładach Mechanicznych Plage i Laśkiewicz w Lublinie) i eklektyczne (budynki mieszkalne przy lubelskiej cukrowni). Kościół konopnicki nie ma bezpośredniego odniesienia do innych prac Sienickiego, jednak nie powinno to dziwić, bowiem architekci tego czasu w zależności od potrzeb inwestora i charakteru budynku dobierali, często na podstawie gotowych wzorników form historycznych i detali architektonicznych, odpowiedni dla danego obiektu „kostium” stylistyczny. W przypadku konopnickiego nowego kościoła być może zamiarem było z jednej strony jasne nawiązanie do średniowiecznej architektury zachodniej Europy na zewnątrz - by świątynia była odbierana w krajobrazie jednoznacznie jako kościół ${ }^{81}$, ale jednocześnie wnętrze Sienicki zaprojektował w bliższych sobie, jak się wydaje, bo częściej przezeń stosowanych, formach architektury inspirowanej włoskim renesansem.

\section{Pieta}

W kościele konopnickim była zapewne przechowywana XV-wieczna gotycka pieta, którą w latach 70. XX wieku pozyskało do swoich zbiorów Muzeum Narodowe w Poznaniu ${ }^{82}$. Znaczenie tego zabytku - wyjątkowego spośród zachowanych obiektów plastyki średniowiecznej na Lubelszczyźnie sprawia iż warto bliżej przyjrzeć się wzmiankom źródłowym na jego temat, dotychczas nie analizowanym. Pierwsze wzmianki o rzeźbie Matki Bożej Bolesnej (Dolorosa) w wielkim ołtarzu pojawiają się w wizytacji z $1675 \mathrm{r}^{83}$ Dokładniejszy opis jest w protokole z 1721 r., gdzie dowiadujemy się, że w środkowej części wielkiego ołtarza znajduje się rzeźba przedstawiająca Matkę Bożą wraz z Chrystusem zdjętym z krzyża (BMV Christum de Cruce depositum $)^{84}$. W wyższej części ołtarza umieszczono

${ }^{80}$ Szczegółowy biogram architekta oraz wykaz jego prac (bez kościoła w Konopnicy): J. Żywicki, Urzędnicy: architekci, budowniczowie, inżynierowie cywilni... Ludzie architektury i budownictwa $w$ województwie lubelskim oraz guberni lubelskiej $w$ Królestwie Polskim $w$ latach 18151915, Lublin 2010, s. 504-506.

${ }^{81}$ Por. J. Żywicki, Architektura neogotycka, s. 127-130.

${ }^{82}$ Szerzej o tym cennym zabytku średniowiecznej rzeźby U. Mazurczak, Greckie $i$ łacińskie warianty Piety. Pieta z Konopnicy w Muzeum Narodowym w Poznaniu, w: Lublin w kulturze, kultura w Lublinie. Dziedzictwo kulturowe miasta od średniowiecza do współczesności, red. P. Dymmel, R. Jop, Lublin 2019, s. 242-256.

${ }^{83}$ AAL, sygn. Rep. 60A 99, Liber visitationum in Archidiaconatu Lublinensi trium decanatuum videlicet Casimiriensis, Parczoviensis, Chodeliensis, k. 167v.

${ }^{84}$ AKMKr, sygn. AV 20, Acta visitationis ecclesiarum archidiaconatus Lublinensis (decanatus: Lucoviensis, Parczoviensis, Casimiriensis, Chodeliensis, civitas Lublinum, decanatus Solecensis) dioecesis Cracoviensis, s. 591. W wizytacji z 1736 r. statuę nazwano jako Złożenie z Krzyża Jezu- 
natomiast obraz Wniebowzięcia Matki Bożej ${ }^{85}$. Wspomniana Pieta była określana w źródle jako stara (vetus) ${ }^{86}$ lub staroświecka (antiqua) $)^{87}$. Rzeźbę wielu uważało za łaskami słynącą (gratiosa) ${ }^{88}$. Wyrazem szczególnej czci wiernych była umieszczona na rzeźbie Maryi srebrna korona z „kamykami czeskimi" ${ }^{89}$ i perełkami oraz liczne wota. W $1721 \mathrm{r}$. zanotowano 26 wotów srebrnych, różnej wielkości ${ }^{90}$. Kult wizerunku wzrastał, co znalazło odzwierciedlenie w rosnącej liczbie wotów. W 1736 r. naliczono 30 wotów srebrnych oraz pięć sznurów koralii" . Wszystkie precjoza, np. paciorki, korale i klejnoty, które zawieszano sukcesywnie przez lata na statui, były wpisywane do inwentarza kościoła ${ }^{92}$. Rzeźbę pozłocono kosztem $50 \mathrm{zł} \mathrm{w} 1763 \mathrm{r}^{93}$

sa Chrystusa (Depositionis de Cruce Domini Jesu Christi), w 1748 r. określono rzeźbę jako Najświętsza Dziewica Bogurodzica Bolesna (Sacratissima Virginis Deipariae Dolorosa). AAL, sygn. Rep 60A 103, Status ecclesiarum decanatus Parczoviensis et Chodoliensis anno Domini millesimo septingentesimo quadragesiom octavo [1748], k. 203; w 1781 r. jako Najświętsza Matka Bolesna. AAL, sygn. Rep 60 A 105, Akta wizyty generalney w trzech dekanatach: chodelskim, urzędowskim y kazimirskim, s. 227.

${ }^{85}$ AKMKr, sygn. AV 20, Acta visitationis ecclesiarum archidiaconatus Lublinensis (decanatus: Lucoviensis, Parczoviensis, Casimiriensis, Chodeliensis, civitas Lublinum, decanatus Solecensis) dioecesis Cracoviensis, s. 591; AAL, sygn. Rep. 60A 101, k. 149v; AAL, sygn. Rep. 60A 103, Status ecclesiarum decanatus Parczoviensis et Chodoliensis anno Domini millesimo septingentesimo quadragesiom octavo [1748], k. 202v

${ }^{86}$ AAL, sygn. Rep. 60A 101, Liber visitationis quatuor decanatuum: Chodelienses, Casimiriensis, Parczoviensis, Solecenzis et aliorum in Archidiaconatu Zavichostiensis, k. 149v.

${ }^{87}$ AAL, sygn. Rep. 60A 103, Status ecclesiarum decanatus Parczoviensis et Chodoliensis anno Domini millesimo septingentesimo quadragesiom octavo [1748], k. 203.

${ }^{88}$ AKMKr, sygn. AV 20, Acta visitationis ecclesiarum archidiaconatus Lublinensis (decanatus: Lucoviensis, Parczoviensis, Casimiriensis, Chodeliensis, civitas Lublinum, decanatus Solecensis) dioecesis Cracoviensis, s. 591; AAL, sygn. Rep 60A 103, Status ecclesiarum decanatus Parczoviensis et Chodoliensis anno Domini millesimo septingentesimo quadragesiom octavo [1748], k. 205.

${ }^{89}$ Określano tak wówczas produkowane w czeskich ośrodkach rzemieślniczych ozdobne szkła imitujące szlachetne kamienie.

${ }^{90} \mathrm{AKMKr}$, sygn. AV 20, Acta visitationis ecclesiarum archidiaconatus Lublinensis (decanatus: Lucoviensis, Parczoviensis, Casimiriensis, Chodeliensis, civitas Lublinum, decanatus Solecensis) dioecesis Cracoviensis, s. 593; AAL, sygn. Rep. 60A 101, Liber visitationis quatuor decanatuum: Chodelienses, Casimiriensis, Parczoviensis, Solecenzis et aliorum in Archidiaconatu Zavichostiensis k. 150.

${ }^{91}$ AAL, sygn. Rep. 60A 101, Liber visitationis quatuor decanatuum: Chodelienses, Casimiriensis, Parczoviensis, Solecenzis et aliorum in Archidiaconatu Zavichostiensis, k. 150. W 1772 r. kościół został okradziony z cenniejszych ruchomości. W $1781 \mathrm{r}$. zanotowano tylko 18 srebrnych wotów ważących 12 grzywien i łod 2. Oszacowano ich wartość na 348 złp. AAL, sygn. Rep 60 A 105, Akta wizyty generalney w trzech dekanatach: chodelskim, urzędowskim y kazimirskim, s. 227.

${ }^{92}$ AKMKr, sygn. AV 20, Acta visitationis ecclesiarum archidiaconatus Lublinensis (decanatus: Lucoviensis, Parczoviensis, Casimiriensis, Chodeliensis, civitas Lublinum, decanatus Solecensis) dioecesis Cracoviensis, s. 593; AAL, sygn. Rep. 60A 101, k. 149v-150.

${ }^{93}$ Księga zgonów parafii Konopnica 1759-1811, dostępna on-line: www.ksiegimetrykalne.pl, brak paginacji. 
O dużej czci dla tej rzeźby wskazuje też fakt, że w 1741 r. podczas procesu plebana z właścicielami Konopnicy o niepłacone dziesięciny, ci poinformowali go, że może utrzymać się ,z łaski Parochianow przy obrazie łaskawym”, ponieważ licznie przybywają do kościoła ${ }^{94}$.

W związku z kultem Piety, corocznie w święto Siedmiu Boleści Maryi, które przypadało w piątek przed Niedzielą Palmową, w konopnickim kościele odprawiana była uroczysta msza św. z wystawieniem Najświętszego Sakramentu. Na dzień ten były przyznane również odpusty ${ }^{95}$. Ponieważ w nabożeństwach brali udział licznie mieszkańcy parafii ${ }^{96}$, dlatego też wizytator w dekrecie reformacyjnym z 1748 r. zobligował plebana do zapraszania kapłanów do słuchania spowiedzi podczas tego odpustu oraz w dzień św. Katarzyny. Ponieważ wspomniany odpust maryjny wypadał w okresie wielkiego postu, pleban dla wyżywienia spowiedników wybudował dwie sadzawki, które zarybi197.

Niestety przebadane źródła nie podają informacji, dlaczego gotycka rzeźba nie znalazła swojego godnego miejsca w XX wieku w nowym kościele, chociaż, w poprzednich wiekach była otoczona dość intensywnym kultem.

\section{Zabudowania kościelne}

Pierwsze opisy budynków plebańskich znajdują się w wizytacji z 1675 r. Dowiadujemy się, że pleban mieszkał w budynku, w którym zajmował małą izbę (hypocaustum) z pokojem (camera). Dla jego rodziny ${ }^{98}$ przeznaczona była piekarnia (pistoria), a dla dzierżawcy (arendatoris) była izba. Było także mieszkanie dla rektora szkoły, które jednak zgniło (putradine), a w środku było klepisko. Natomiast w mieszkaniu dla kantora uległ spaleniu dach. Dom leżący naprzeciw piekarni wynajmował rzemieślnik (artificus). Wspomniano, że nie było stodoły i stajni, co jak wiemy, powodowało konieczność przechowywania narzędzi rolniczych i płodów rolnych w kościele i kostnicy 9 .

Kolejny opis zabudowań kościelnych z 1721 r. jest bardziej szczegółowy. Dom plebański znajdował się przy cmentarzu i składał się z murowanej małej izby z pokojem. W mieszkaniu były dwa okna, z posadzką i sufitem wykona-

${ }^{94}$ AAL, sygn. Rep 60A 103, Status ecclesiarum decanatus Parczoviensis et Chodoliensis anno Domini millesimo septingentesimo quadragesiom octavo [1748], k. 205.

${ }^{95}$ AAL, sygn. Rep. 60A 101, Liber visitationis quatuor decanatuum: Chodelienses, Casimiriensis, Parczoviensis, Solecenzis et aliorum in Archidiaconatu Zavichostiensis, k. 149v.

${ }^{96}$ AAL, sygn. Rep 60A 103, Status ecclesiarum decanatus Parczoviensis et Chodoliensis anno Domini millesimo septingentesimo quadragesiom octavo [1748], k. 205.

${ }^{97}$ Koszt wykonania i zarybienia stawów wyniósł 650 zł. AAL, sygn. Rep 60A 103, Status ecclesiarum decanatus Parczoviensis et Chodoliensis anno Domini millesimo septingentesimo quadragesiom octavo [1748], k. 203v, 206.

${ }^{98}$ Być może chodzi tu o służbę kościelną (ministri) lub plebańską (famuli). W źródle zapisani jako „familia”. AAL, sygn. Rep. 60A 99, Liber visitationum in Archidiaconatu Lublinensi trium decanatuum videlicet Casimiriensis, Parczoviensis, Chodeliensis, k. 168;

${ }^{99}$ AAL, sygn. Rep. 60A 99, Liber visitationum in Archidiaconatu Lublinensi trium decanatuum videlicet Casimiriensis, Parczoviensis, Chodeliensis, k. 168; ArKMKr, sygn. AV 9, Liber visitationis externae ecclesiarum in decanatu Chodeliensi, k. $52 \mathrm{v}$. 
nym z drewnianych desek. Drzwi miały żelazne zawiasy. Były także dwie izby drewniane z dachem słomianym oraz kuchnia. Do budynków gospodarczych należała naprawiona drewniana stodoła, kryta strzechą. Była również jedna stajnia. W ogrodzie za domem niedawno wybudowano piwnicę. Za ogrodem był staw rybny i nowy browar „sprawiony dla pożytku Parocha" ${ }^{100}$. Zbudowane były także czterech domki dla dzierżawców (inquilinis), którym też zostały przekazane do uprawy różne pola ${ }^{101}$. Wspomniane domki zamieszkiwali najprawdopodobniej trzej poddani (subditos) kościoła. Jeden z nich pracował trzy dni w tygodniu „pieszo”, drugi dwa dni w tygodniu, a trzeci jeden dzień w tygodniu ${ }^{102}$. Nie było żadnej służby kościoła ${ }^{103}$.

Wizytator zanotował również w 1721 r, że w Konopnicy był nowo zbudowany drewniany szpital (hospital), na który jednak nie było fundacji. Ubodzy (pauperes) otrzymywali jałmużnę i choć mieszkali we wsiach, schodzili się jednak zawsze do kościoła ${ }^{104}$. Zaskakująca jest informacja z kolejnej wizytacji (1736), kiedy pojawia się wpis, że nigdy nie było w parafii w Konopnicy szpitala (xenodochium) choć we wsi są ubodzy ${ }^{105}$, co przeczy poprzedniej wiadomości.

W 1736 r. odnotowano jednak sługi kościelne (ministri Ecclesiae), którymi byli: organista Józef Czyrwinski z żoną oraz dzwonnik Andrzej Jaroszowski, również żonaty. Poddanymi kościoła (subditi) ${ }^{106}$ byli: żonaty Franciszek Jasinski z trzema synami oraz jego stary ojciec Mateusz Jasinski ${ }^{107}$. Wspomniani słudzy kościelni i poddani otrzymywali za swoją pracę od plebana 12 florenów i 5 gro$\mathrm{szy}^{108}$.

Podczas lustracji w 1748 r. pleban ks. Jan Mateusz Stargowski stwierdził, że kiedy obejmował parafię, zastał kościół i zabudowania plebańskie w ruinie.W związku z tym musiał wyremontować świątynię i wystawić swoim sumptem plebanię, ogród i staw rybny ${ }^{109}$. Zabudowania te zostały postawione na powierzchni pół łana, ale niezbyt ściśle, pomiędzy drogami: publiczną lubelską, boczną drogą

100, „...) pro commodo (...) Parochi”. AKMKr, sygn. AV 20, Acta visitationis ecclesiarum archidiaconatus Lublinensis (decanatus: Lucoviensis, Parczoviensis, Casimiriensis, Chodeliensis, civitas Lublinum, decanatus Solecensis) dioecesis Cracoviensis, s. 595.

101 Tamże.

102 Tamże.

103 Tamże.

104 Tamże.

${ }^{105}$ AAL, sygn. A 101, Acta visitationis decanatuum: Casimiriensis, Parczoviensis, Chodeliensis et Solecensis archidiaconatus Lublinensis et aliarum in archidiaconatu Zavichostensi ex annis 17361739, k. 152.

${ }^{106} \mathrm{~W}$ wizytacji z 1748 r. byli oni określeni jako dzierżawcy (inquilinis). Zob. AAL, sygn. Rep 60A 103, Status ecclesiarum decanatus Parczoviensis et Chodoliensis anno Domini millesimo septingentesimo quadragesiom octavo, k. 204-204v.

${ }^{107}$ AAL, sygn. A 101, Acta visitationis decanatuum: Casimiriensis, Parczoviensis, Chodeliensis et Solecensis archidiaconatus Lublinensis et aliarum in archidiaconatu Zavichostensi ex annis 17361739, k. $151 \mathrm{v}$.

108 Tamże.

${ }^{109}$ AAL, sygn. Rep 60A 103, Status ecclesiarum decanatus Parczoviensis et Chodoliensis anno Domini millesimo septingentesimo quadragesiom octavo [1748], k. 204. 
prowadzącą do wsi, drogą biegnącą z dworu od zachodu oraz drogą prowadzącą od południa do domów i dworu. Budynki kościelne były położone pośrodku tej ostatniej drogi. Budynki plebańskie (aedificia) m.in. wozownia (holodium) były ciasne (stricta). Plebania była murowana ale z gliny (murata sed argilla) i bardzo ciasna (valde strictae). Dlatego też teraźniejszy proboszcz dostawił do niej drewnianą izbę. Na przeciw plebani wybudował stajnię dla koni, a dla bydła małą oborę ${ }^{110}$. Dodatkowo pleban postawił budynki mieszkalne dla dzierżawców (inquilinis): Franciszka Jasinskiego z żoną i dziećmi oraz Pawła Jakubczaka. Trzecie mieszkanie zajął zakrystian Mikołaj Aleksandrowicz z żoną i dziećmi. Wspomniani pracowali dwa dni w tygodniu, otrzymując $\mathrm{z}$ dobrowolnej ofiary 20 florenów. Natomiast przez pięć dni służyli Kościołowi, nie pobierając zapłaty ${ }^{111}$. Jak zapisał wizytator, koszt postawienia nowych budynków gospodarczych i mieszkania dla komorników i zakrystiana wyniósł $280 \mathrm{zł}^{112}$.

Po upływie ponad 30 lat, stan budynków uległ destrukcji i podczas wizytacji w $1781 \mathrm{r}$. zanotowano, że aktualny pleban ks. Adam Martynowicz wzniósł nową plebanię i budynki gospodarcze. W nowej plebanii były dwie izby i sień. Izba plebańska składała się z alkierza, kominka i dwóch narożników. Naprzeciw niej znajdowała się izba czeladna z komorą. Obie miały kominy wywiedzione nad dach, przed połową podmurowane. Na wzgórku pod sadem stał spichlerz, pod którym była piwnica drewniana (rznięta), z szyją (wejściem ze schodami z powierzchni terenu) tylko z kamieni murowaną z gliną. Stodoła o dwóch boiskach, miała czworo drzwi. Nieopodal stodoły znajdowała się obora z chlewami. Trzymano tam jedną parę wołów, cztery krowy i parę koni.

Naprzeciw plebanii był browarek ze stajenką i izbą, w której stał piec do suszenia i mały kociołek do piwa. Na dole, poniżej kościoła był również budynek o czterech izbach, który posiadał jeden komin. Zamieszkiwał w nim organista, krawiec i dwóch komorników, którzy pracowali jeden dzień w tygodniu. Jeden z nich miał ogródek. Za ogrodem były dwie małe sadzawki. Dodatkowo były cztery chałupy, w których mieszkali chłopi. Pracowali oni sprzężajem dwa razy w tygodniu. Przy swoich chałupach mieli stodółki i chlewki ${ }^{113}$.

W 1781 r. organistą w parafii konopnickiej był Stefan Warchowski, mający 16 lat. Funkcję sługi kościelnego i zakrystiana pełnił, nie wymieniony z nazwiska, 28 letni mężczyzna ${ }^{114}$.

W 1800 roku na cmentarzu przykościelnym, mimo jego niewielkich rozmiarów, znajdował się także dom mieszkalny dla służby kościelnej ${ }^{115}$. W pobliżu, po południowo-wschodniej stronie kościoła były zabudowania parafii: plebania, wozownia, stajenka, stodoła, „obory w czworogran”, spichlerz i chlew ${ }^{116}$, zapewne

${ }^{110}$ Tamże, k. 204, 206.

${ }^{111}$ Tamże, k. 204v.

112 Tamże, k. 205v-206.

${ }^{113}$ AAL, sygn. Rep 60 A 105, Akta wizyty generalney w trzech dekanatach: chodelskim, urzędowskim y kazimirskim, s. 230.

114 Tamże, s. 232.

${ }^{115}$ AAL, Rep. 60A 182, Actus vitationis generalis decanatus Lublinensis, s. 271.

116 Tamże, s. 284-285. 
tożsame z wymienionymi w roku 1781. Zabudowania te są widoczne na pochodzącej z lat 1801-1804 mapie Heldensfelda ${ }^{117}$ oraz na późniejszym, nieco bardziej szczegółowym planie z roku $1867^{118}$.

\section{Cmentarz parafialny}

Cmentarz w Konopnicy, położony dziś w granicach administracyjnych Lublina, powstał na początku XIX w. Nie został on zaznaczony na znajdującej się w wiedeńskim Kriegsarchiv tzw. Mapie Heldensfelda, ale już tzw. Mapa Kwatermistrzostwa, wydana w 1843 r., ale sporządzona wg wcześniejszych pomiarów, ukazuje jego lokalizację. Kilkukrotnie powiększany w swojej historii, do dziś zachował kilkadziesiąt starych, zabytkowych nagrobków, niestety stopniowo z jego przestrzeni znikających, mimo wpisu cmentarza do rejestru zabytków w 1985 r. (nr rejestru A/942). Oprócz licznych grobów mieszkańców parafii konopnickiej, na cmentarzu znajdują się też nagrobki konopnickich księży oraz dawnych właścicieli majątku Konopnica. Wśród tych ostatnich, także architekta Władysława Wołłodki, żyjącego w latach 1866-1929, autora m.in. kościołów w Łomazach, Parczewie i Sławatyczach ${ }^{119}$.

\section{Konopniccy plebani}

Na podstawie zachowanych protokołów wizytacji biskupich możemy ustalić listę plebanów konopnickich (zwanych często zamiennie: rector, pleban, parochus, praepositus). W 1611 r. rektorem był Jan Blisowski (?) ${ }^{120}$. W 1675 r. zanotowano plebana Jana Gałęskiego, który był też rektorem szpitala w Lublinie ${ }^{121}$.

Natomiast rządcy kościoła w Konopnicy w XVII wieku według ustaleń ks. J. Stargowskiego z wizytacji z 1748 r. ${ }^{122}$ to: Jan Putkowski (?) (1633-1673); Kazimierz Baczyński (1674-1682)123; Gaiowski (1683-1700); Rzędowski (1701-1709) i Albert Paszkowski (1710) ${ }^{124}$.

117 Kriegsarchiv Wien, dostępna on-line: https://mapire.eu/en/map/europe-18century-firstsurvey/ (dostęp: 10.09.2019)

${ }^{118}$ AAL, Rep. 60B IVb 85, Akta kościoła parafialnego Konopnica, brak paginacji.

${ }^{119} \mathrm{O}$ Wołłodce szerzej J. Żywicki, Urzędnicy: architekci, budowniczowie, inżynierowie cywilni, s. 524-525.

${ }^{120}$ ArKMKr, sygn. AV 6, Acta visitationis interioris archidiaconatus Lublinensis, cuius possessorem tangit ius visitandi in decanatibus: Lucoviensi, Parczoviensi, Chodeliensi, Kazimiriensi et Solecensi, in anno Domini 1617, diebus Iunii et Iulii, opera commissaria R.D. Iacobi Piaseczki, decani Kielcensis, canonici Posnaniensis confecta, k. 30-62, k. 30.

${ }^{121}$ AAL, sygn. Rep. 60A 99, Liber visitationum in Archidiaconatu Lublinensi trium decanatuum videlicet Casimiriensis, Parczoviensis, Chodeliensis, k. 168.

${ }^{122}$ AAL, sygn. Rep 60A 103, Status ecclesiarum decanatus Parczoviensis et Chodoliensis anno Domini millesimo septingentesimo quadragesiom octavo [1748], k. 206.

${ }^{123}$ Według wizytacji z 1675 r. plebanem był Jan Gałęski. AAL, sygn. Rep. 60A 99, Liber visitationum in Archidiaconatu Lublinensi trium decanatuum videlicet Casimiriensis, Parczoviensis, Chodeliensis, k. 168.

${ }^{124} \mathrm{Wg}$ Spisu prepozytów i plebanów diecezji krakowskiej, ks. Paszkowski miał imię Wojciech i był plebanem do 1711 r. Zob. Szczepaniak, Spis prepozytów i plebanów diecezji krakowskiej, s. 176. 
W 1711 r. parafię w Konopnicy objął pochodzący z diecezji chełmskiej Jan Mateusz Stargowski ${ }^{125}$, urodzony w 1688 r. Poprzednio był on wikariuszem w Skierbieszowie i kaznodzieją w Warężu. Został instalowany przez właścicieli Konopnicy: Helenę i Marcina Trębinskich (Trębińskich) ${ }^{126}$.

Plebanem konopnickim w 1781 r. był ks. Adam Martynowicz ${ }^{127}$, urodzony 2 kwietnia 1723 r. Swięcenia kapłańskie przyjął 23 lipca 1751 r. Z prezenty Michała Siekierzyńskiego, podstolego owruckiego ${ }^{128}$, objął parafię w Konopnicy w 1759 r. W dniu 24 marca 1781 r. odprawił rekolekcje, a zgodę na słuchanie spowiedzi uzyskał 22 sierpnia 1780 r. ${ }^{129}$

\section{Uposażenie parafii}

Uposażenie parafii w Konopnicy zostało nadane przez radę miejską Lublina w 1428 r., w środę po święcie Bożego Ciała. Było ono oblatowane w Konsystorzu Lubelskim 14 stycznia 1610 r. ${ }^{130} \mathrm{~W}$ skład uposażenia, według wizytacji z $1675 \mathrm{r}$. wchodziły dwa łany pola, które rozciągały się od wsi Zemborzyce do granicy wsi Radawiec. Z powodu niedbalstwa rządcy zaczęły one jednak zarastać do tego stopnia, że na części gruntu rósł wówczas las ${ }^{131}$.

${ }^{125}$ AKMKr, sygn. AV 20, Acta visitationis ecclesiarum archidiaconatus Lublinensis (decanatus: Lucoviensis, Parczoviensis, Casimiriensis, Chodeliensis, civitas Lublinum, decanatus Solecensis) dioecesis Cracoviensis, s. 594. W wizytacji z 1736 r. i 1748 r. zapisano datę instalacji plebana na 1711 r. AAL, sygn. A 101, Acta visitationis decanatuum: Casimiriensis, Parczoviensis, Chodeliensis et Solecensis archidiaconatus Lublinensis, s. 149; sygn. Rep 60A 103, Status ecclesiarum decanatus Parczoviensis et Chodoliensis anno Domini millesimo septingentesimo quadragesiom octavo [1748], k. 204v. Natomiast wizytacja z 1748 r. informuje, że ks. Jan M. Stargowski mieszka w parafii 36 lat czyli od 1712 r., AAL, sygn. Rep 60A 103, Status ecclesiarum decanatus Parczoviensis et Chodoliensis anno Domini millesimo septingentesimo quadragesiom octavo [1748], k. 204v. J. Szczepaniak w swoim Spisie prepozytów i plebanów diecezji krakowskiej podaje dzień instalacji na 19 X 1711 r. Zob. Szczepaniak, Spis prepozytów i plebanów diecezji krakowskiej (XVIII w.), Kraków 2008, s. 176.

${ }^{126}$ AAL, sygn. A 101, Acta visitationis decanatuum: Casimiriensis, Parczoviensis, Chodeliensis et Solecensis archidiaconatus Lublinensis, s. 149; AAL, sygn. Rep 60A 103, Status ecclesiarum decanatus Parczoviensis et Chodoliensis anno Domini millesimo septingentesimo quadragesiom octavo [1748], k. 204v.

${ }^{127} \mathrm{~W}$ publikacji J. Szczepaniaka Spis prepozytów i plebanów diecezji krakowskiej podane jest imię Jan. Zob. Szczepaniak, Spis prepozytów i plebanów diecezji krakowskiej, s. 176.

${ }^{128}$ Siekierzyński h. Kościesza Michał, był podstolim owruckim w latach 1712-1765. Zob. Urzędnicy województw kijowskiego i czernihowskiego XV-XVIII wieku, opr. E. Janas, W. Kłaczewski, Kórnik 2002, s. 92, 320.

${ }^{129}$ AAL, sygn. Rep 60 A 105, Akta wizyty generalney w trzech dekanatach: chodelskim, urzędowskim y kazimirskim, s. 232; Szczepaniak, Spis prepozytów i plebanów diecezji krakowskiej, s. 176.

${ }^{130}$ AKMKr, sygn. AV 20, Acta visitationis ecclesiarum archidiaconatus Lublinensis (decanatus: Lucoviensis, Parczoviensis, Casimiriensis, Chodeliensis, civitas Lublinum, decanatus Solecensis) dioecesis Cracoviensis, s. 594.

${ }^{131}$ ArKMKr, sygn. AV 9, Liber visitationis externae ecclesiarum in decanatu Chodeliensi, s. 52; AAL, sygn. Rep. 60A 99, Liber visitationum in Archidiaconatu Lublinensi trium decanatuum videlicet Casimiriensis, Parczoviensis, Chodeliensis, k. 168. 
Parafii nadana była również ziemia, na której stały kościół z plebanią w środku wsi. Był to grunt o szerokości dwóch łanów od rzeki do drogi publicznej do Lublina. W kierunku zaś dróg miał długość pół łana ${ }^{132}$. Uposażenie gruntowe parafii wzrosło w XVIII wieku, gdyż w 1721 r. zanotowano, że parafia posiadała cztery łany pola ornego oraz dwa ogrody ${ }^{133}$. Jednak pleban użytkował tylko trzy łany, ponieważ 12 zagonów zajął kolator kościoła. Dlatego też pozwał go do sądu $\mathrm{z}$ żądaniem zwrotu wspomnianego pola ${ }^{134}$.

W kolejnej wizytacji (1748) szczegółowo opisano grunty, w jakie była uposażona parafia w Konopnicy. Były to pola za Konopnicą, pomiędzy granicą wsi królewskiej Zemborzyce i wsi Radawiec oraz między drogami publicznymi do Urzędowa i Bełżyc. Od drogi do Urzędowa w kierunku do granic wsi Zemborzyce było przeznaczonych pod zasiew 11 stajów, a reszta tworzyła kłujące zarośla (silvis rubetis). Od drogi do Urzędowa, pomiędzy drogą do Bełżyc i granicy Radawca było 14 stajów. Tylko połowę tych łanów użytkował pleban, ponieważ resztą władał kolator kościoła ${ }^{135}$.

Parafia konopnicka nie zwiększyła stanu posiadania gruntów, co zauważamy w lustracji z $1781 \mathrm{r}$. Nadal miała cztery łany pola ornego. Jeden łan był w Siedlisku, o długości stu zagonów, po 6 skib w każdym zagonie, ciągnący się do gościńca w kierunku Lublina. Od drogi tej miał on mniej niż trzydzieści zagonów do granic Wrotkowa. Tylko 15 stajów tego łanu było obsiane, a reszta zarosła lasem. Drugi łan ciągnął się od drogi do Trzeszkowic (Strzeszkowic), pod lasem. Miał on szerokość 125 zagonów i ciągnął się do granic zemborskich. Zasiewanych było tylko 10 stajów, a reszta zarosła lasem. Trzeci łan był po drugiej stronie drogi do Trzeszkowic i ciągnął się do granic Radawca 22 stajami. Był on szeroki na 60 zagonów. Od granicy Radawca łan ten miał 58 zagonów. Czwarty łan miał długość 40 zagonów, ciągnących się do Konopnicy i był zarośnięty krzakami. Pod lasem, od drogi do Trzeszkowic (Strzeszkowic), ciągną się do granic Radawca na szerokość 40 zagonów. Od domu do Radawca łan miał długość 50 zagonów i szerokość 22 stajów ${ }^{136}$.

$\mathrm{Z}$ wymienionych pól w 1780 r. pleban konopnicki zebrał: pszenicę ( 5 korcy, 30 kop), żyto (20 korcy, kop 60), grykę (tatarka) - (14 korcy, 50 kop), owies (10 korcy, $30 \mathrm{kop}$ ) i groch (3 ćwierci korcy, kop 7). W następnym roku na pola plebańskie wysiano żyto (26 korcy), grykę (14 korcy), owies (10 korcy) oraz posadzono 1 korzec grochu. Zrezygnowano z siewu pszenicy, którą zastąpiono jęczmieniem $(8 \text { korcy })^{137}$.

${ }^{132}$ ArKMKr, sygn. AV 9, Liber visitationis externae ecclesiarum in decanatu Chodeliensi, s. 52; AAL, sygn. Rep. 60A 99, Liber visitationum in Archidiaconatu Lublinensi trium decanatuum videlicet Casimiriensis, Parczoviensis, Chodeliensis, k. 168.

${ }^{133}$ AKMKr, sygn. AV 20, Acta visitationis ecclesiarum archidiaconatus Lublinensis (decanatus: Lucoviensis, Parczoviensis, Casimiriensis, Chodeliensis, civitas Lublinum, decanatus Solecensis) dioecesis Cracoviensis, s. 594-595.

${ }^{134}$ Tamże, s. 595.

${ }^{135}$ AAL, sygn. Rep 60A 103, Status ecclesiarum decanatus Parczoviensis et Chodoliensis anno Domini millesimo septingentesimo quadragesiom octavo [1748], k. 202v.

${ }^{136}$ AAL, sygn. Rep 60 A 105, Akta wizyty generalney w trzech dekanatach: chodelskim, urzędowskim y kazimirskim, s. 231

${ }^{137}$ Tamże. 
Na dochody plebana składały się nie tylko zyski ze sprzedaży wyżej wymienionego zboża i innych płodów rolnych, ale również dziesięciny ${ }^{138}$ ze wsi Konopnica, Radawiec i Uniszowice. W 1780 r. łączny jego dochód wyniósł 640 złp. ${ }^{139}$

Wydatki, które musiał ponosić pleban były różnego rodzaju i obejmowały podatki (subsidium charitativum, podymne), wynagrodzenie księżom, którzy pomagali plebanowi w duszpasterstwie, opłacenie światła i inne potrzeby kościoła, zapłata organiście, gospodyni, parobkom do wołów i koni, chłopcu i dziewczynie (dziewce), zakup mięsa i soli. Ponadto pleban płacił za siano dla zwierząt gospodarskich, pracujących żniwiarzy i grabarzy oraz na naprawę wozów, bron i innych narzędzi rolniczych. Łącznie w 1780 r. wydatki wyniosły 758 złp $^{140}$.

\section{BIBLIOGRAFIA}

\section{Źródla archiwalne}

Archiwum Archidiecezjalne Lubelskie

Konsystorz Generalny Lubelski

sygn. Rep. 60A 99, Liber visitationum in Archidiaconatu Lublinensi trium decanatuum videlicet Casimiriensis, Parczoviensis, Chodeliensis [1675].

sygn. Rep. 60A 101, Liber visitationis quatuor decanatuum: Chodelienses, Casimiriensis,

Parczoviensis, Solecenzis et aliorum in Archidiaconatu Zavichostiensis [1738-1739]. sygn. A 97, Visitatio ecclesiarum in Archidiaconatu Lublinensi [1644, 1650].

sygn. A 101, Acta visitationis decanatuum: Casimiriensis, Parczoviensis, Chodeliensis et

Solecensis archidiaconatus Lublinensis et aliarum in archidiaconatu Zavichostensi ex annis 1736-1739.

sygn. Rep. 60A 103, Status ecclesiarum decanatus Parczoviensis et Chodoliensis anno Domini millesimo septingentesimo quadragesiom octavo [1748].

sygn. Rep. 60 A 105, Akta wizyty generalney w trzech dekanatach: chodelskim, urzędowskim y kazimirskim z woli y rozkazu Jaśnie Oświeceonego Imci x. Kajetana Ignacego Sołtyka, biskupa krakowskiego, xiążęcia siewierskiego przez x. Franciszka Dunina Kozickiego, kollegiaty pileckiey dziekana od dnia 15 maja w Roku 1781 poczętej, a w roku 1782 dniach ostatnich miesiąca stycznia odprawioney i dokończoney spisane. sygn. Rep. 60A 182, Actus visitationis generalis decanatus Lublinensis [1800].

sygn. Rep. 60B IVb 84, Fundusze, Budowle, Cmentarze kościoła parafialnego w Konopnicy [1817-1938].

sygn Rep. 60B IVb 85. Akta kościoła parafialnego Konopnica [1882-1896].

Archiwum Kurii Metropolitalnej w Krakowie,

sygn. AVCap. 65, Compendium actorum visitationis ecclesiarum decanatus Chodeliensis et Parczoviensis, ad archidiaconatum Lublinensem pertinentium, per R.D. Petrum

${ }^{138}$ Przez cały XVIII w. trwały spory sądowe plebana z właścicielami majątku w Konopnicy o niewypłacanie dziesięcin

${ }^{139}$ AAL, sygn. Rep 60 A 105, Akta wizyty generalney w trzech dekanatach: chodelskim, urzędowskim y kazimirskim, s. 231.

${ }^{140}$ Tamże, s. 231-232. 
Skidziński, archidiaconum Zawichostensem factae et modo, quo sequitur, conscriptae anno 1611, in Octobre.

sygn. AV 6, Acta visitationis interioris archidiaconatus Lublinensis, cuius possessorem tangit ius visitandi in decanatibus: Lucoviensi, Parczoviensi, Chodeliensi, Kazimiriensi et Solecensi, in anno Domini 1617, diebus Iunii et Iulii, opera commissaria R.D. Iacobi Piaseczki, decani Kielcensis, canonici Posnaniensis confecta, k. 30-62.

sygn. AV 9, Liber visitationis externae ecclesiarum in decanatu Chodeliensi, per me, Petrum Dobielowicz, decanum Chodeliensem, parochum Opoliensem, commissarium ab R.D. Andrea Trzebicki, episcopo Cracoviensi, duce Severiae, datum et deputatum, conscriptus A.D. 1675.

sygn. AV 20, Acta visitationis ecclesiarum archidiaconatus Lublinensis (decanatus: Lucoviensis, Parczoviensis, Casimiriensis, Chodeliensis, civitas Lublinum, decanatus Solecensis) dioecesis Cracoviensis, ex commissione R.D. Constantini Feliciani Szaniawski, episcopi Cracoviensis, ducis Severiae, per R.D. Ioannem Felicem Szaniawski, episcopum Capsensem, suffraganeum, archidiaconum et officialem generalem Leopoliensem, expedita et connotata anno 1721.

Archiwum Państwowe w Lublinie

Komisja Województwa Lubelskiego i Rząd Gubernialny Lubelski, sygn. 594 I 595.

Akta Gminy w Konopnicy (z siedzibą w Lublinie), sygn. 295.

\section{Źródla drukowane}

Długosz J., Liber beneficiorum dioecesis cracoviensis nunc primum e codice autographo editus, t. 2, wyd. A. Przedziecki, Kraków 1864.

\section{Opracowania}

Chachaj J., Rozwój struktur parafialnych na obszarze Lublina do połowy lat 70. XX wieku, w: Lublin. Historia dzielnic w 700. rocznice lokacji miasta, red. J. Chachaj, H. Mącik, D. Szulc, Lublin 2017, s. 7-22.

Dzieje Lubelszczyzny, t. 3: Słownik historyczno-geograficzny województwa lubelskiego w średniowieczu, opr. S. Kuraś, Warszawa 1983.

Hamryszczak A., Mącik H., Parafia i kościół w Zemborzycach w XVIII-XIX wieku, „Archiwa, Biblioteki i Muzea Kościelne”, 106 (2016) s. 55-74.

Hamryszczak A., Mącik H., Parafia i kościoły w Abramowicach w XVII-XIX wieku, „Archiwa, Biblioteki i Muzea Kościelne”, 107 (2017) s. 145-166.

Kumor B., „Spis ludności diecezji krakowskiej prymasa M.J. Poniatowskiego z 1787 r.”, „Archiwa, Biblioteki i Muzea Kościelne”, 35 (1977) s. 255-283.

Kołacz-Chmiel M., Elity chłopskie w Polsce w XV-XVI wieku (Rodziny Bąków-Tomczyków i Zegadtów w podlubelskiej wsi Konopnica), „Średniowiecze Polskie i Powszechne”, 7 (2011) s. 186-204.

Księga sadowa podlubelskiej wsi Konopnicy 1521-1555, opr. G. Jawor, M. Kołacz-Chmiel, Lublin 2009.

Mazurczak U., Greckie i łacińskie warianty Piety. Pieta z Konopnicy w Muzeum Narodowym w Poznaniu, w: Lublin $w$ kulturze, kultura $w$ Lublinie. Dziedzictwo kulturowe miasta od średniowiecza do współczesności, red. P. Dymmel, R. Jop, Lublin 2019, s. $242-256$.

Miłobędzki A., Architektura polska XVII wieku, Warszawa 1980.

Nadolski B., Orientacja (Conversi ad Dominum), w: Leksykon liturgii, red. B. Nadolski, Poznań 2006, s. 1132. 
Rachwał P., Spis ludności parafii Konopnica z 1760 roku, „Przeszłość Demograficzna Polski”, 38 (2016) nr 2, s. 117-133.

Rola A., Historia podlubelskiej wsi Konopnica do połowy XVI wieku, „Rocznik Lubelski”, 39 (2013) s. 9-19.

Słowik K., Konopnica, woj. lubelskie. Studium historyczno-ruralistyczne, Lublin 1991, mps, Archiwum Wojewódzkiego Urzędu Ochrony zabytków w Lublinie, sygn. 2130.

Sochacka A., Własność ziemska w województwie lubelskim w średniowieczu, Lublin 1987.

Szczepaniak J., Spis prepozytów i plebanów diecezji krakowskiej (XVIII w.), Kraków 2008.

Węglin, Szerokie, red. H. Mącik, D. Szulc, J. Chachaj, Lublin 2017.

Szczęch E., Dawny kościół reformatów - obecnie browar-Dąbrowskiego 15 w Lublinie, Lublin 1973, mps, Archiwum WUOZ Lublin.

Trzewik M., Klasztor reformatów w Lublinie, w: Druga szansa zakładów przemysłowych Vetter w Lublinie, red. K. Czerlunczakiewicz, H. Mącik, M. Trzewik, Lublin 2018, s. $15-36$

Urzędnicy województwa lubelskiego XVI-XVIII wieku, red. A. Gąsiorowski, oprac. W. Kiełczewski, W. Urban, Kórnik 1991.

Urzędnicy województw kijowskiego i czernihowskiego XV-XVIII wieku, opr. E. Janas, W. Kłaczewski, Kórnik 2002.

Wnuk A.U., Dzieje parafii Popkowice: 600 lat historii, Urzędów 2004.

Żywicki J., Architektura neogotycka na Lubelszczyźnie, Lublin 1998.

Żywicki J., Urzędnicy: architekci, budowniczowie, inżynierowie cywilni... Ludzie architektury $i$ budownictwa $w$ województwie lubelskim oraz guberni lubelskiej $w$ Królestwie Polskim w latach 1815-1915, Lublin 2010.

\section{Netografia}

Kriegsarchiv Wien, Mapa Heldensfelda, https:/mapire.eu/en/map/europe-18century-firstsurvey/ (dostęp: 10.09.2019). 


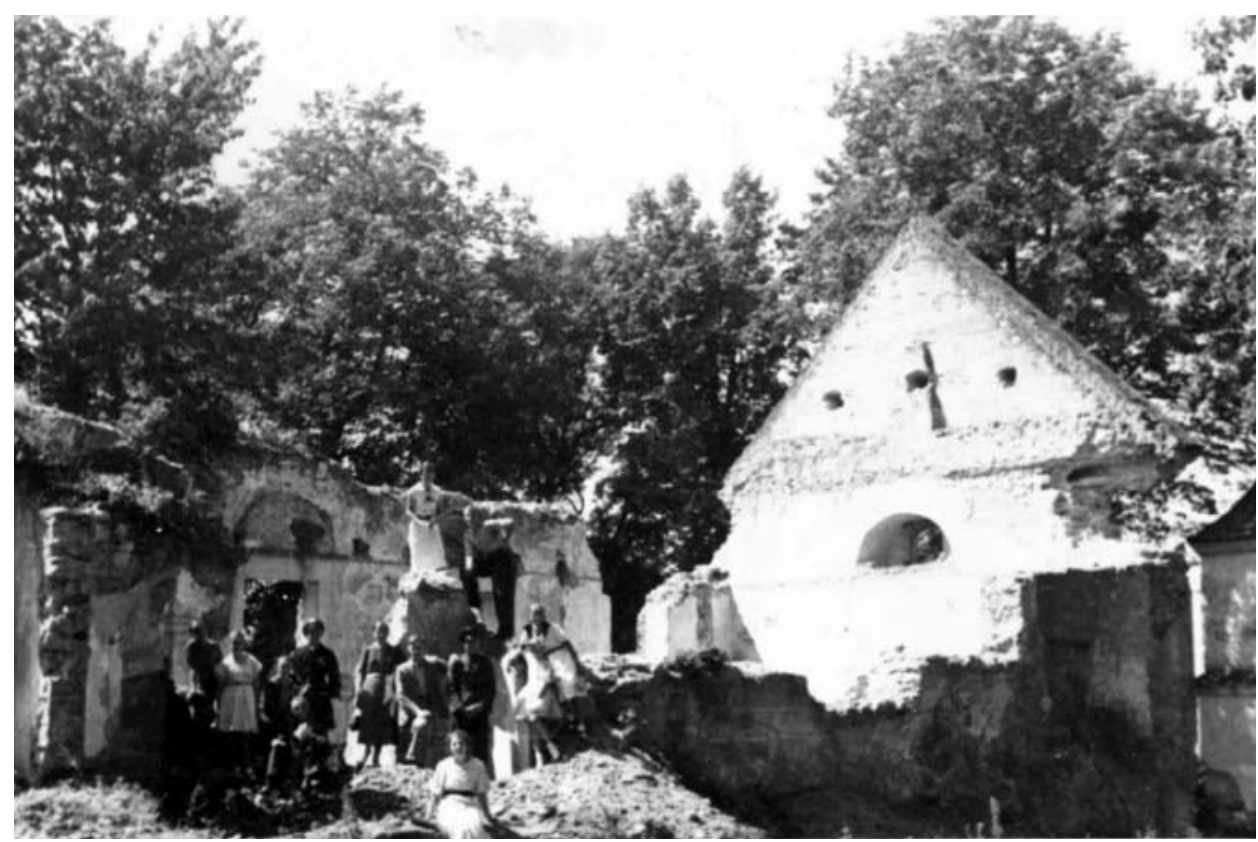

Fot. 1. Fotografia archiwalna ruin starego kościoła w Konopnicy ze zbiorów Teresy Wiśniewskiej, lata 20. XX wieku, za: „Echo Konopnicy”, nr 5-6/2019, s. 9.

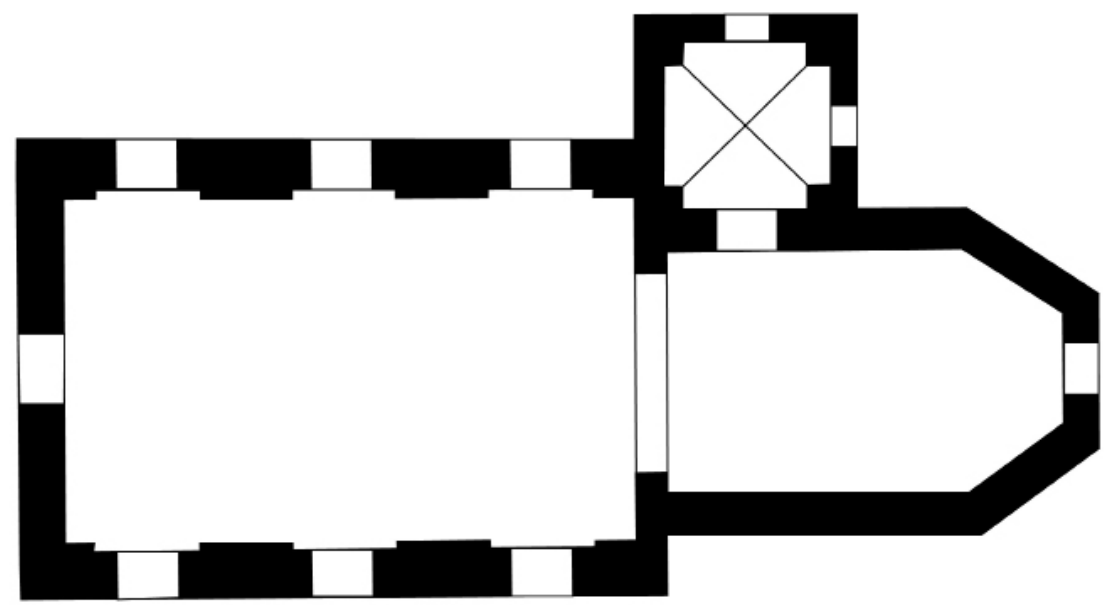

Fot. 2. Próba rekonstrukcji rzutu starego kościoła w Konopnicy.

Oprac. Hubert Mącik. 


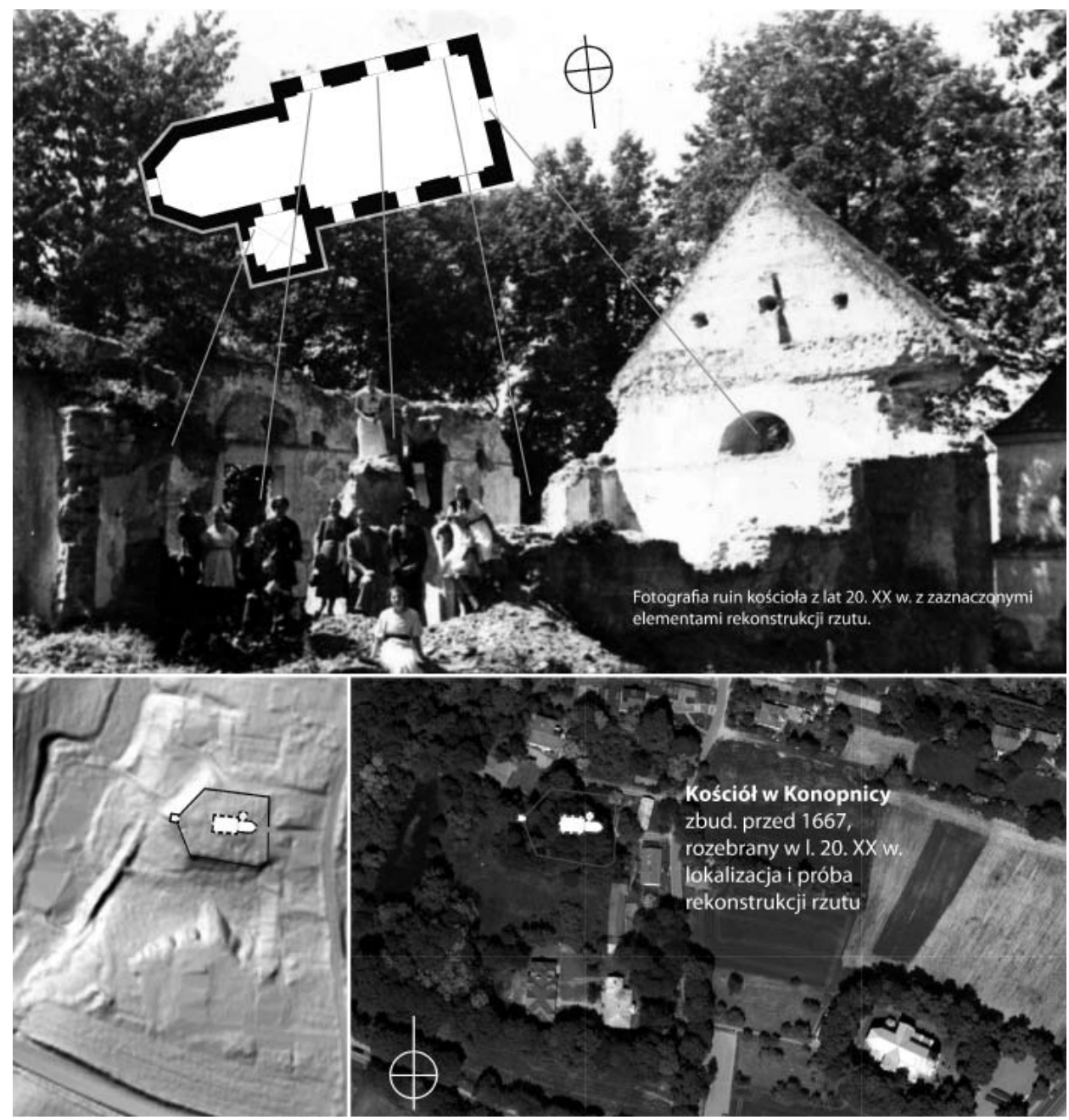

Fot. 3. Rekonstrukcja rzutu starego kościoła w Konopnicy i jego lokalizacji w terenie. Oprac. Hubert Mącik 


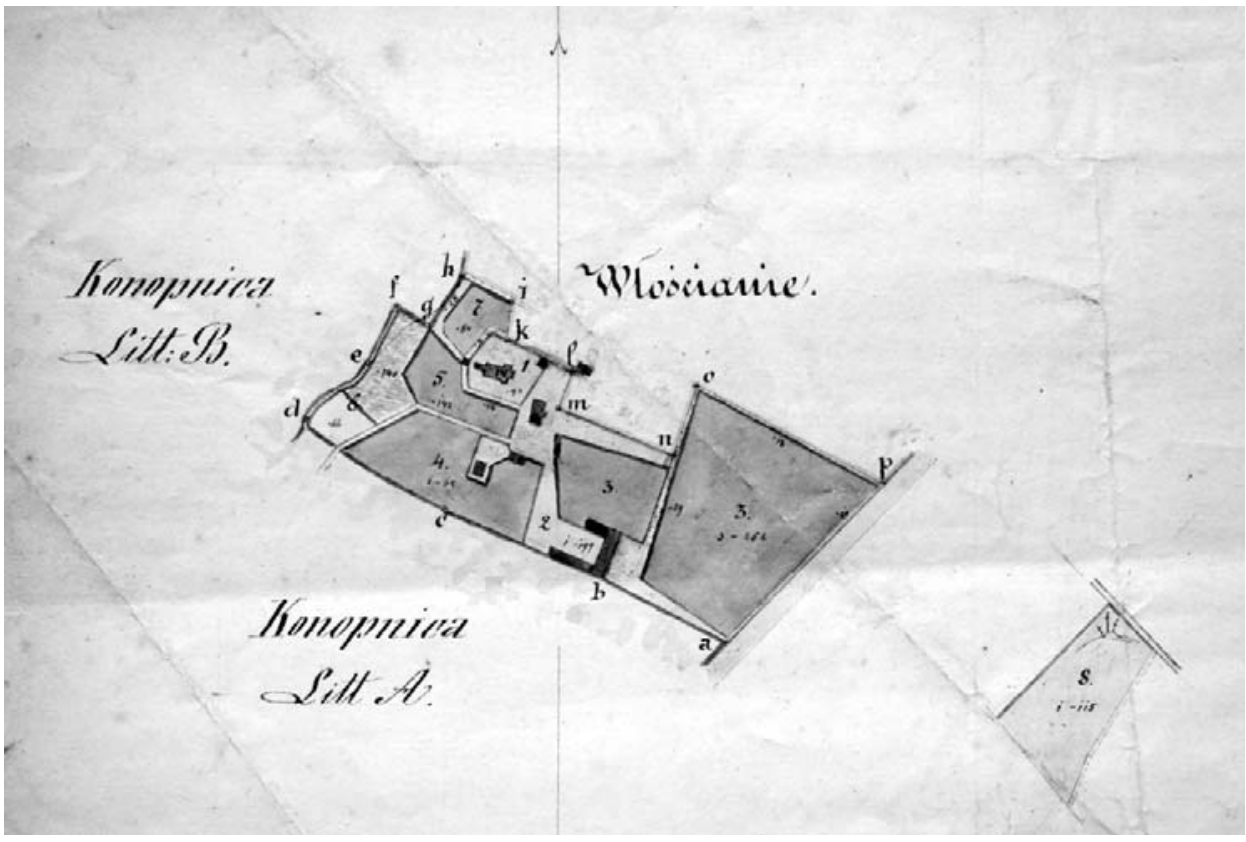

Fot. 4. Fragment planu gruntów probostwa Konopnica geometry K. Wójcickiego, 1867, AAL, Rep. 60B IVb 85, brak paginacji.

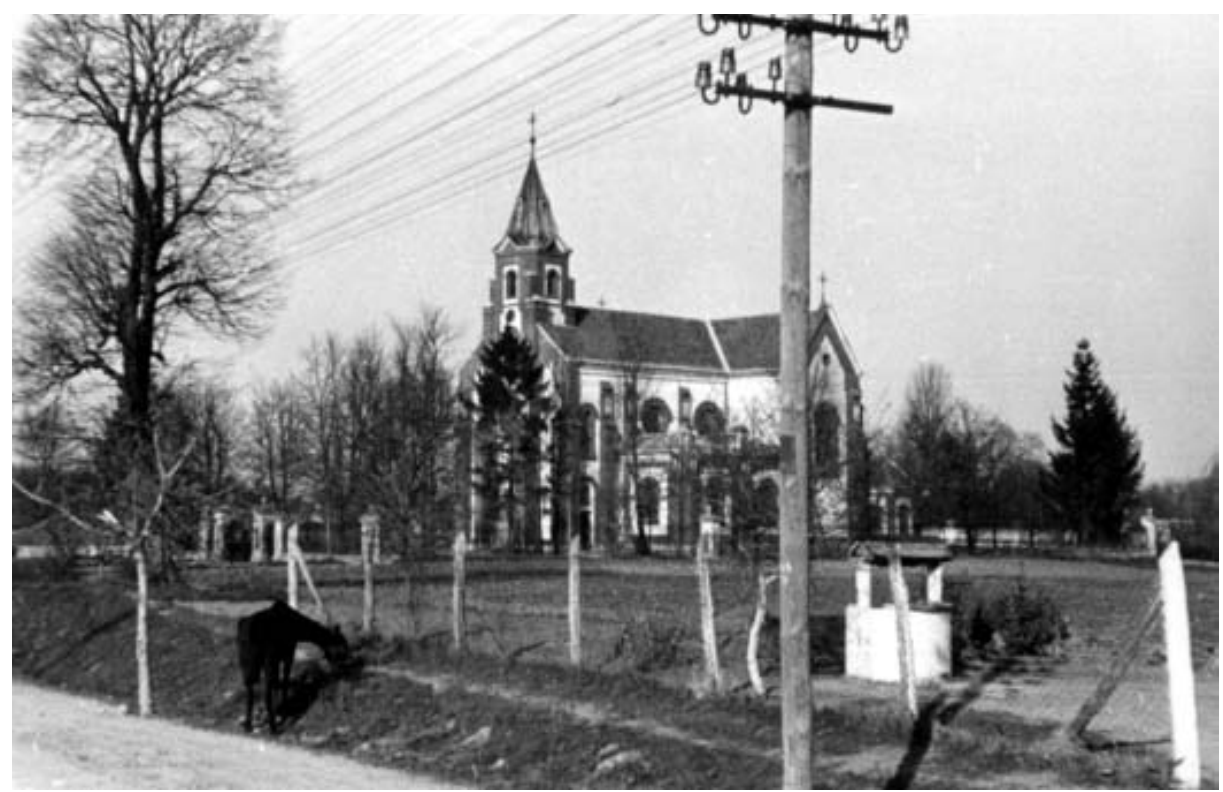

Fot. 5. Nowy kościół w Konopnicy, lata 40. XX wieku. Zbiory Huberta Mącika. 


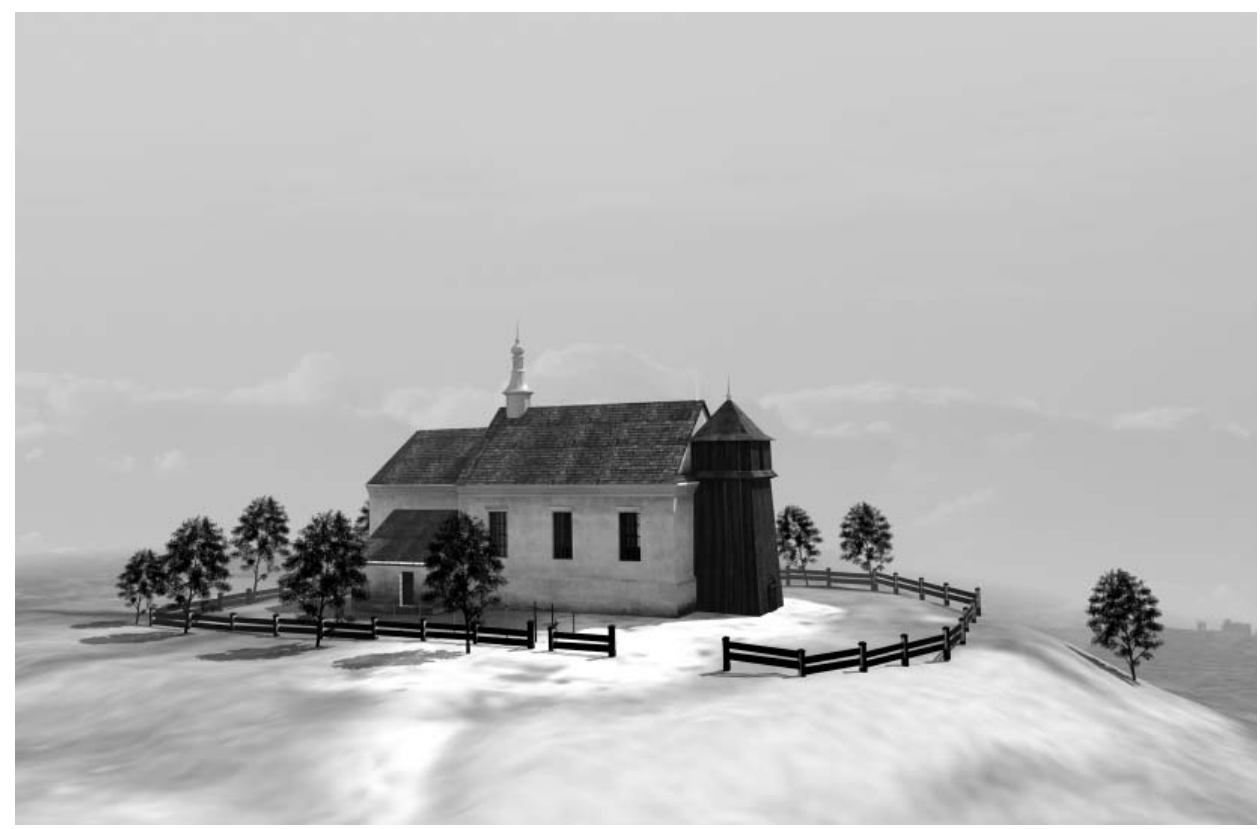

Fot. 5. Rekonstrukcja bryły starego kościoła w Konopnicy wg opisu z $1721 \mathrm{r}$. Oprac. Jarosław Sim.

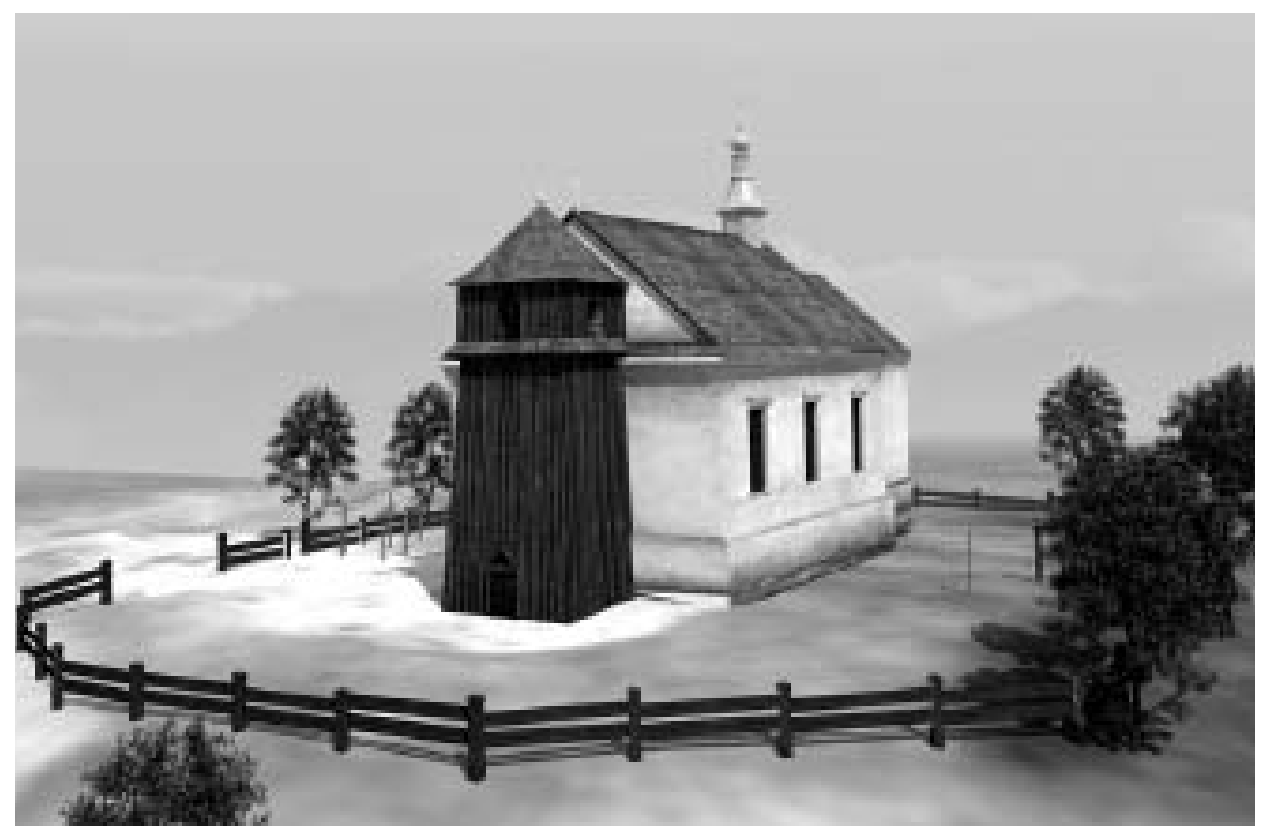

Fot. 6. Rekonstrukcja bryły starego kościoła w Konopnicy wg opisu z 1721 r. Oprac. Jarosław Sim. 


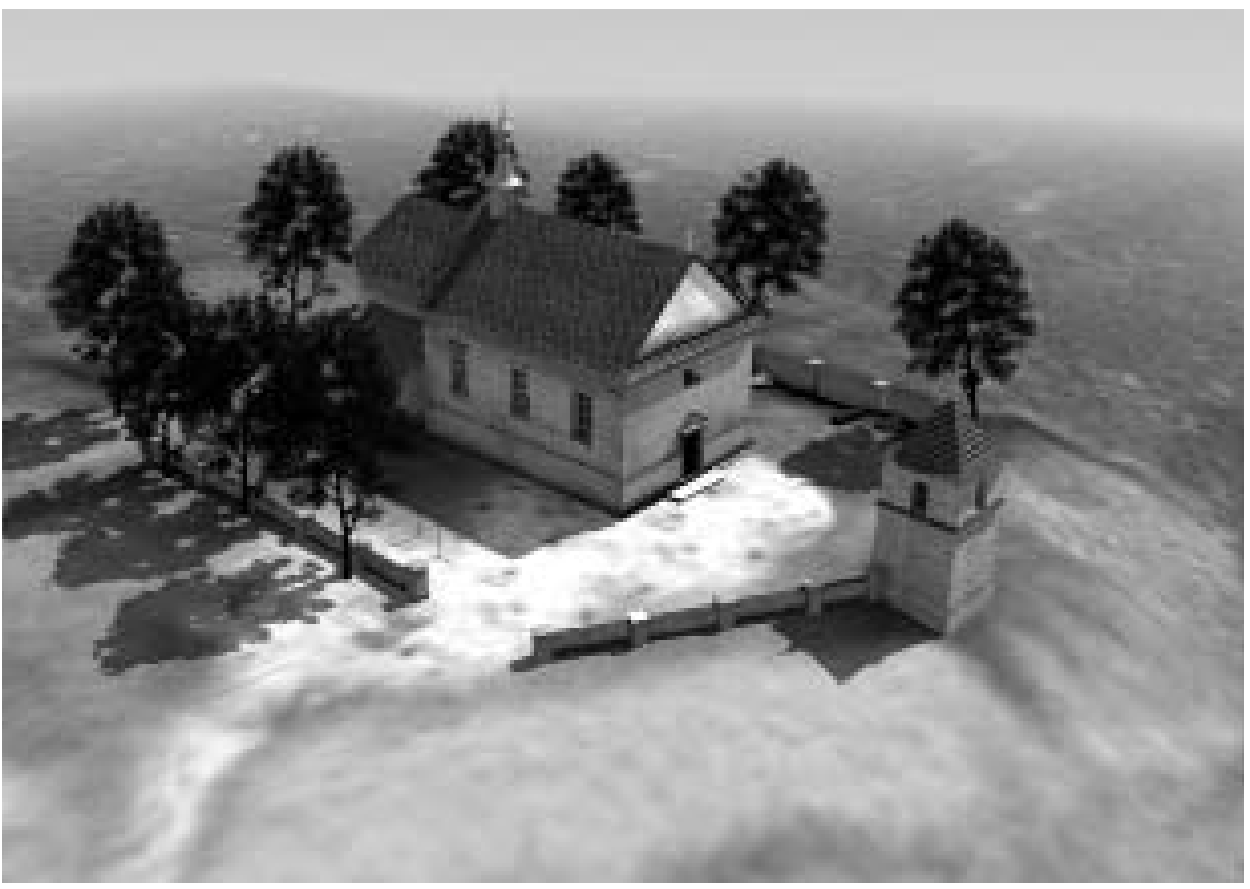

Fot. 7. Rekonstrukcja bryły starego kościoła w Konopnicy ok. 1800 r. Oprac. Jarosław Sim.

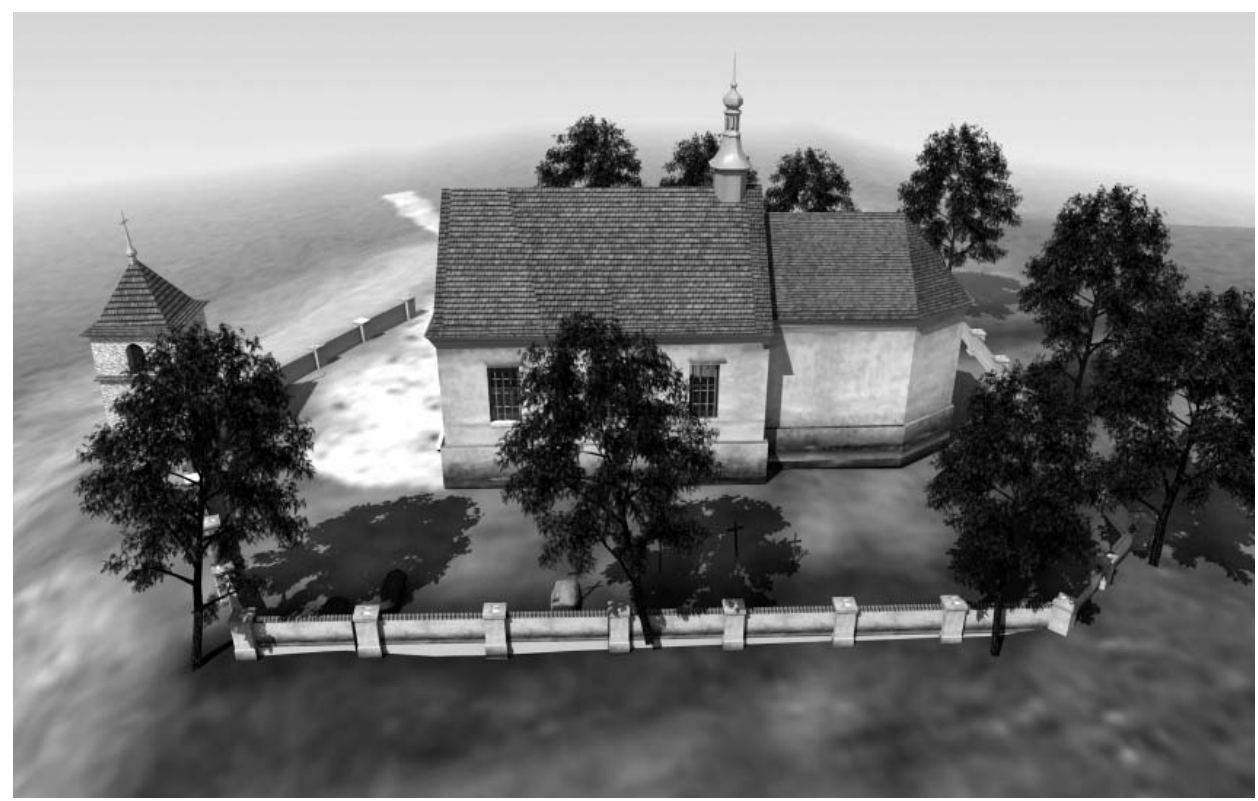

Fot. 8. Rekonstrukcja bryły starego kościoła w Konopnicy ok. 1800 r. Oprac. Jarosław Sim. 


\section{CHURCHES AND PARISH BUILDINGS IN KONOPNICA FROM THE SEVENTEENTH TO THE TWENTIETH CENTURY}

\section{Summary}

The parish of Konopnica in the Lublin district and the archdeaconry of Lublin dates back to the fourteenth century. It encompassed three villages located next to each other: Konopnica, Radawiec and Uniszowice. At the end of the eighteenth century the parish already had six villages, apart from the abovementioned ones, Radawczyk, Motycz and Sporniak. It was not until the interwar period that the parish borders were changed; the parish of Motycz was established at the time.

The church was endowed by the authorities of the city of Lublin in 1428 . The oldest wooden St Catherine's church was replaced with a stone church, built on a headland protruding into the river valley and consecrated in 1667 . At that time the church was dedicated to the Assumption of the Blessed Virgin Mary, as well as St Catherine.

The eclectic church, designed by Władysław Siennicki and erected in 19041906, took the place of the one from the seventeenth century (it was, however, built on a different site from the previous one). The church serves its functions to this day. The decision to build a new church was prompted by an increasing number of parish inhabitants, the poor technical condition of the existing church, and the project of the Kraśnik road, which became the main road from Lublin to Kraśnik. After the new church had been built, the old church of the seventeenth century fell into oblivion and was demolished in the interwar years.

The Konopnica church boasted a sculpture of a Gothic Pietà, which is currently held at the National Museum in Poznań. The sculpture, placed in the high altar, was considered to be miraculous and was worshipped by the local population. Every year on the feast of the Seven Sorrows of Mary (the Friday before Palm Sunday), the Blessed Sacrament was exposed following the celebration of holy mass, during which the faithful were granted an indulgence.

The condition of the parish and the church in Konopnica was described in detail in canonical visitation records. In addition to the church, the parish possessed a presbytery, flats for church servants, a hospital, and outbuildings, such as a coach house, a stable, a pigsty, a granary, and a brewery. The new parish cemetery, which replaced the cemetery located near the church, was opened in the early nineteenth century and is currently in the national register of historic monuments.

Key words: Konopnica; Pietà; the parish of Konopnica; the archdeaconry of Lublin; Władysław Sienicki; sacral architecture 